\title{
Organic-Inorganic Geochemical Characteristics of the Upper Permian Pusige Formation in a High-Saline Lake Basin, Tarim Basin: Implications for Provenance, Paleoenvironments, and Organic Matter Enrichment
}

\author{
Jingbin Wang $\mathbb{D}^{\mathrm{D}},{ }^{1,2,3}$ Zhiliang He $\mathbb{D}^{\mathrm{D}},{ }^{1,2,4}$ Dongya Zhu $\mathbb{D}^{2},{ }^{2,3}$ Zhiqian Gao, $^{1}$ Xiaowei Huang, ${ }^{1,2,3}$ \\ and Quanyou Liu ${ }^{2,3}$ \\ ${ }^{1}$ China University of Geosciences (Beijing), Beijing 100083, China \\ ${ }^{2}$ State Key Laboratory of Shale Oil and Gas Enrichment Mechanisms and Effective Development, Beijing 100083, China \\ ${ }^{3}$ Petroleum Exploration and Production Research Institute, SINOPEC, Beijing 100083, China \\ ${ }^{4}$ Department of Science and Technology, SINOPEC, Beijing 100728, China \\ Correspondence should be addressed to Jingbin Wang; 476559034@qq.com
}

Received 6 January 2021; Revised 27 February 2021; Accepted 3 March 2021; Published 7 April 2021

Academic Editor: Kun Zhang

Copyright ( 2021 Jingbin Wang et al. This is an open access article distributed under the Creative Commons Attribution License, which permits unrestricted use, distribution, and reproduction in any medium, provided the original work is properly cited.

\begin{abstract}
The third member (M3) of the Upper Permian Pusige Formation is a prominent organic-rich lacustrine mudstone sequence within the Yecheng-Hetian Sag, Tarim Basin, hosting major petroleum resources. However, its depositional history and organic matter $(\mathrm{OM})$ enrichment mechanism have received little attention. Therefore, various organic and inorganic geochemical analyses were performed on thirty-four core samples from the Well DW1, to elucidate their depositional paleoenvironments, provenance, and tectonic setting, as well as the controlling factors of OM enrichment. Results showed that the M3 mudstones are classified as poor- to fair-quality hydrocarbon source rocks with mature type II-III kerogen, considering their low organic geochemical parameters. Paleosalinity indexes (e.g., Beq, Sr/Ba, and B/Ga) indicated the typical high-saline lacustrine water body, in which redox state was the oxic-dysoxic as suggested by multiple indicators. Many paleoclimate and weathering proxies suggest a dominant semiarid condition and low weathering degree in the Yecheng-Hetian Sag, which led to that weathered felsic rocks from the West Kunlun Orogen to the southwest of basin were quickly transported into the lake basin. Detrital materials carrying nutrient elements finally promoted the development of relatively high paleoproductivity indicated by fairly high $\mathrm{P} / \mathrm{Ti}$ and $\mathrm{Ba} / \mathrm{Al}$ ratios. The negative relationship between $\mathrm{P} / \mathrm{Ti}$ and total organic carbon (TOC) indicates that paleoproductivity was not the main controlling factor. The correlations among TOC and $\mathrm{P} / \mathrm{Ti}$ and other multiple proxies suggest that the OM enrichment can be interpreted as both the "preservation model" and "dilution model." Although the water body was relatively oxygen-riched, high sedimentation rate could largely shorten the exposure time of OM with oxygen, thus decreased the decomposition of OM. In particular, the high-saline, stratified lake water may also restrain the degradation of OM. Furthermore, detrital dilution exerted a potential effect on TOC abundances. On the basis of the above results, a developing model was established to decipher the formation mechanism of OM in these M3 mudstones.
\end{abstract}

\section{Introduction}

In recent decades, much attention has been drawn to the formation mechanism of organic matter (OM) in both marine and lacustrine fine-grained sediments. Three fundamental models have been put forward, including (i) higher organic productivity, (ii) enhanced OM preservation (associated with oxygen-deficiency condition in bottom water and sedimentation rate), and (iii) OM dilution (minimal detrital material input) $[1-11]$. However, the main controlling factors on the formation of organic-rich sediments remain to be controversial. This is because that in most cases, the formation of $\mathrm{OM}$ 
(a)

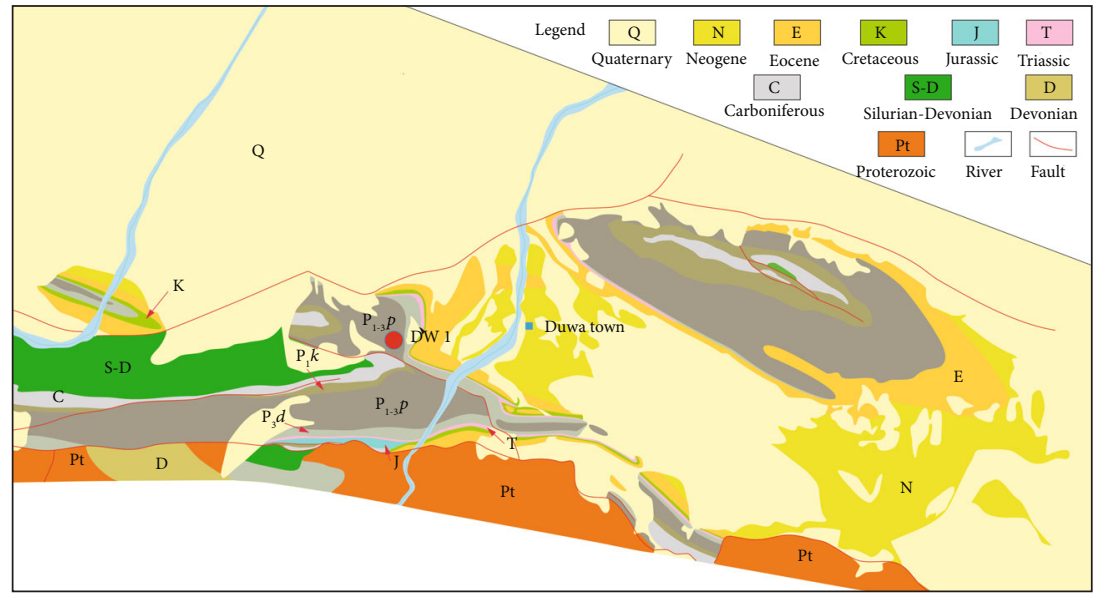

$\square$ Keziliqiman formation $\left(\mathrm{P}_{1} k\right)$

$\square$ Pusige formation $\left(\mathrm{P}_{1-3} p\right)$

$\square$ Duwa formation $\left(\mathrm{P}_{3} d\right)$ (b) c)
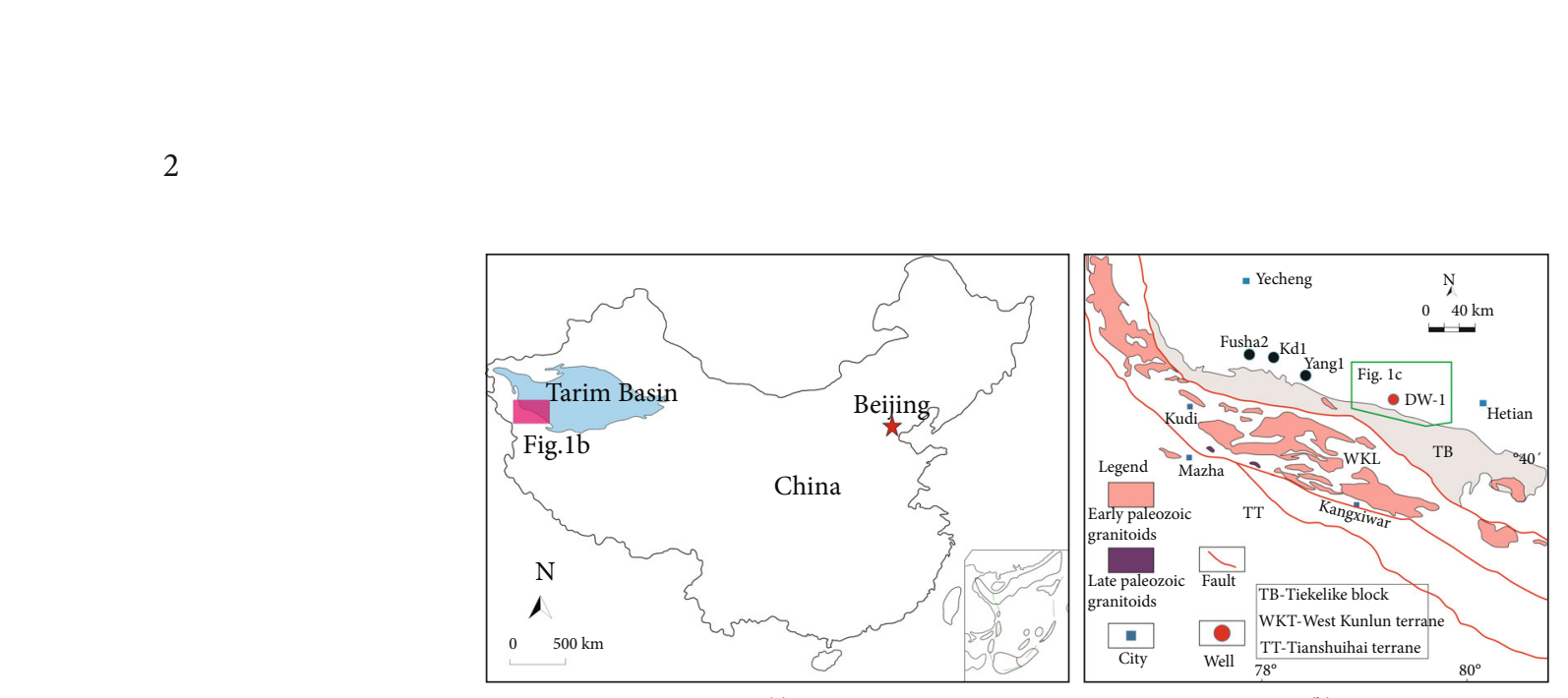

Figure 1: (a) Location of the Tarim Basin and the study area within Northwest China. (b) Sketch map showing major structural units and distribution of Paleozoic granitoids within the West Kunlun Orogen, and location of the investigated Well DW1 in the southwest of Tarim Basin (modified after Jiang et al. [37]; Wang et al. [39]). (c) Simplified geological map showing the distribution of the Pusige Formation strata in the Hetian area (modified after Henan Institute of Geological Survey [42]).

is the result of the complicated, nonlinear interactions among these controlling factors, and also each basin has its own specific factors $[1,4,12,13]$.

Organic-rich mudstones in lacustrine basins can be regarded as favorable hydrocarbon source rocks or direct unconventional petroleum resources (e.g., shale oil and shale gas) $[14,15]$; however, their formation processes are much more complicated than those in marine basins, since terrigenous influx and paleoclimate can exert a substantial influence on the evolution of restricted lacustrine basins [16, 17]. Fortunately, continuous geochemical data of lacustrine sediments are used to reconstruct the depositional paleoenvironments at that time, which contributes to a better understanding of OM enrichment in lacustrine basins $[9,12$, 18-20].

The Yecheng-Hetian Sag is currently one of the most potential petroliferous areas in the Tarim Basin [21-26]. The Permian organic-rich marls (Qipan Formation) and lacustrine mudstones (Pusige Formation) are two sets of important source rocks because of their widespread distributions in the study area and relatively high organic geochemical properties [23-25]. According to the results of the oilsource correlation results $[21,23,24]$, the lacustrine mud- stones in the third member (M3) of the Upper Permian Pusige Formation studied herein are potentially the dominant hydrocarbon source rocks for the Kekeya oil/gas field and Well KD-1. The Pusige Formation sediments were just developed during one basin-mountain transition process that basin type was transferred from the Carboniferous-late Early Permian retroarc extensional basin to late Late Permian typical foreland basin. Previous studies mainly focused on their stratigraphic sequences, paleontology, sedimentary facies, and hydrocarbon source rock evolution [27-31]. However, few studies have been made regarding the depositional paleoenvironments (e.g., paleoclimate, weathering, sedimentation rate, and water-mass properties), provenance attribute, and tectonic setting during the deposition of Pusige Formation, which limits the understanding of controlling factors for OM accumulation within the mudstones in the Yecheng-Hetian Sag.

Therefore, in this study, many reliable organic parameters and inorganic elemental indicators were well screened to clarify the depositional paleoenvironments, provenance characters, and mechanism of OM enrichment, as well as the developing model of these Permian Pusige Formation lacustrine mudstones. This study not only provides a more 


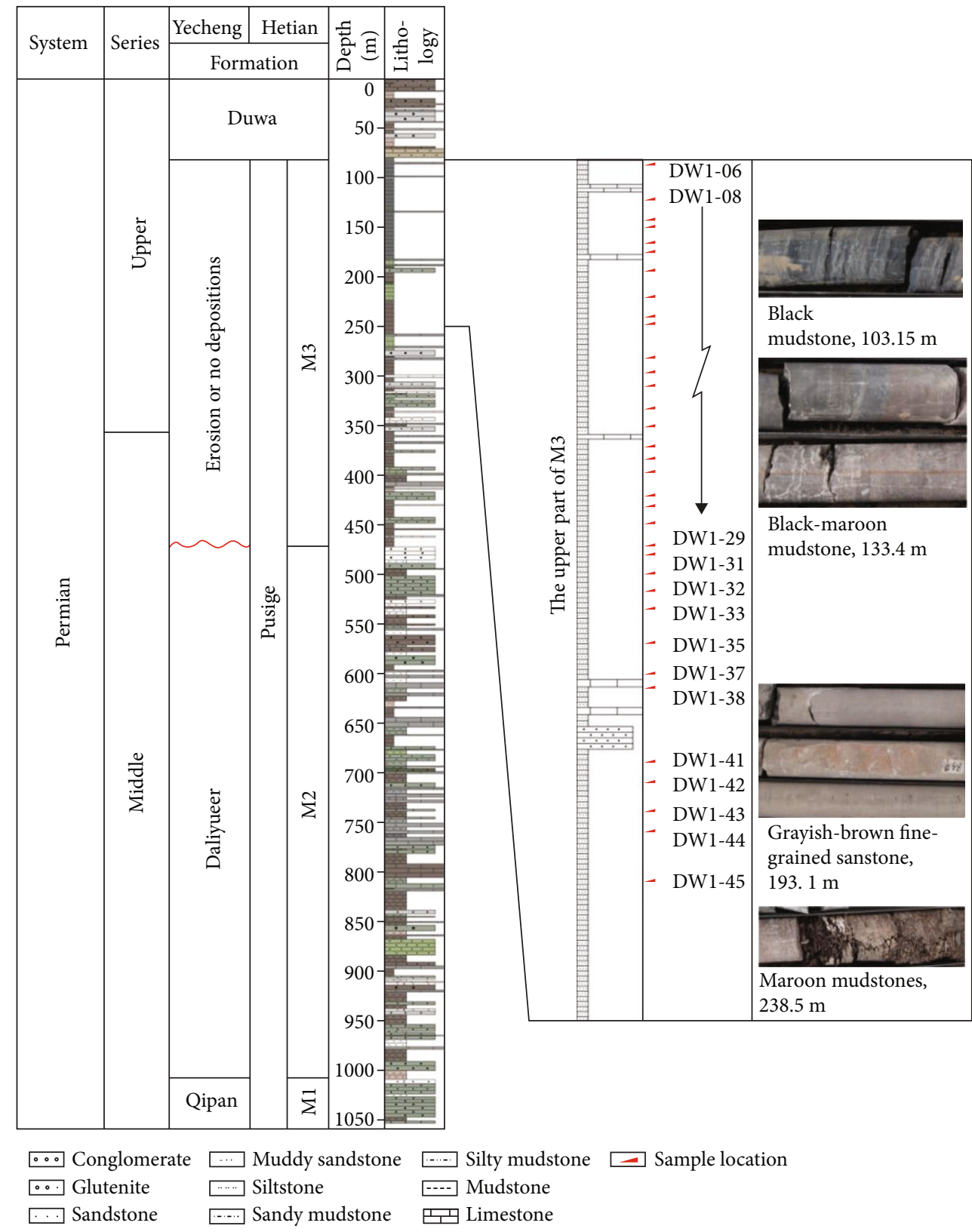

Figure 2: Permian stratigraphy in Yecheng-Hetian Sag, and the generalized stratigraphic column for the Pusige Formation and the sampling locations of the M3 mudstones in Well DW1.

comprehensive cognition of the depositional history for Pusige Formation sediments and guide the future petroleum explorations in Southwestern Tarim Basin but also acts as a reference for $\mathrm{OM}$ enrichment in other high-saline lake basins.

\section{Geological Setting}

Tarim Basin is a typical superimposed polycyclic intracratonic basin developed on the Precambrian basements [22, 32-34]. The Southwestern Tarim Basin is sandwiched between the Tianshan Mountain to the north and Kunlun Mountain to the southwest. The investigations of tectonic cycles, basin prototype, stratigraphic sequence, and geomor- phologic recovery suggest that the sedimentary and tectonic evolution of the southwestern Tarim Basin is closely correlated to the uplift and extrusion of the West Kunlun Orogen [22, 32-34]. Six tectonic-stages can be identified, namely, the Stage I: Sinian-Ordovician passive continental margin stage; Stage II: Silurian-Middle Devonian peripheral foreland basin; Stage III: Late Devonian-Early Permianpassive continental margin stage; Stage IV: Late Permian-Triassic back-arc foreland basin; Stage V: Jurassic-Paleogene intracontinental depression; and Stage VI: Neogene-Quaternary compound foreland basin. The investigated Permian continental sediments were just deposited at the transition of Stage III and IV. In addition, following the opening and closure of the Tethys oceans, many Paleozoic intrusive plutons were widely 
formed within the Kegang, Kudi, Mazha, and Kangxiwar regions (Figure 1), which are mainly composed of granite and granodiorite associated with continental island arc- and continental margin-related tectonic settings [35-40].

The Yecheng-Hetian Sag is a subtectonic unit located in the southwestern Tarim Basin. The evolution of the Permian sedimentary basin is thought to be directly controlled by the closure of the Kangxiwar Paleo-Tethys [27, 41]. Kangxiwar Paleo-Tethys is particularly one of the key regions to investigate the geological evolution of West Kunlun Orogen and Tarim plate. At the beginning of the Early Carboniferous, open marine platform facies, commenced with a large-scale transgression that represents one of the greatest sea-level rises in geological history, covered extensively in YechengHetian Sag and developed marine carbonate rocks with thousands of meters in thickness until the late Early Permian [41]. At the beginning of the late Early Permian, the Kangxiwar Paleo-Tethys moved intensively northward towards the Tarim Plate with a relatively high angle, leading to an enhanced uplift and the intense regression of sea-level in the Hetian region relative to the Yecheng region [27-29, 41]. As a result, depositional systems in the Yecheng and Hetian regions show remarkable differences [27]. A marine environment was still dominated in the Yecheng region, whereas continental clastic depositions began to be widely developed in the Hetian region (Figure 1(c)) [42]. Two stratigraphic successions were then established and include the Keziliqiman, Qipan, and Daliyueer formations in Yecheng region, and the Keziliqiman, Pusige, and Duwa formations in the Hetian region from Early to Late Permian (Figure 2) [27]. Notably, the Pusige Formation spans the Lower, Middle, and Upper series of the Permian [31] and can be informally divided into three continuous members: Member 1 (M1), Member 2 (M2), and Member 3 (M3) [23, 25, 29, 30].

The investigated Well DW1 was an important exploratory well, which was located in the west of Duwa town (Figure 1(c)) [42]. This well explored the Pusige Formation and Duwa Formation strata, with a total thickness of 1 $050 \mathrm{~m}$ (Figure 2). The lithology included the conglomerate, sandstone, siltstone, and mudstone interbedded with some gypsum and limestone layers, which were likely deposited in fan-delta to shore-shallow-deep lacustrine facies [23, 28, 29]. In the upper part of M3, black-gray, maroon, and graygreen mudstones are the dominant lithofacies, with a total thickness of approximately $170 \mathrm{~m}$ in this profile. This mudstone section can be correlated with other drilling wells (e.g., Yang 1 and Fusha 2) and outcrops (e.g., Duwa and Wuluwusitang), which were deposited in the semideep lacustrine facies based on the sedimentary structures (e.g., horizontal bedding), fossils (e.g., fish skeleton) and lithofacies $[23,28]$. The M3 black mudstones are widely distributed within the Yecheng-Hetian Sag with a vertical thickness up to $565.0 \mathrm{~m} \mathrm{[23].}$

\section{Samples and Methods}

A total of thirty-four core samples were collected from the mudstone section $(82.0 \sim 223.0 \mathrm{~m})$ in Well DW1, with an average spacing of $3.4 \mathrm{~m}$ (Figure 2), and then subjected to various geochemical analyses.

TOC and total sulfur (S) were determined using a Leco CS-400 apparatus. Prior to analysis, powdered samples (approximately 100 mesh) were dissolved by dilute $\mathrm{HCl}$ $(\sim 8 \%)$ to remove carbonate minerals (inorganic carbon) for 12 hours. Rock-Eval pyrolysis was conducted on the powdered samples using a Rock-Eval VI instrument. The free hydrocarbon $S_{1}$ was measured at $300^{\circ} \mathrm{C}$, and generated hydrocarbon $S_{2}$ was identified at a temperature of $600^{\circ} \mathrm{C}$. Potential generation index (PG, $\left.S_{1}+S_{2}\right)$ and hydrocarbon index (HI, $S_{2} \times 100 /$ TOC) were calculated to reveal the hydrocarbon generation potential. These experiments were performed at the Yangtze University, China.

Major elements were detected by a wavelength dispersive $\mathrm{X}$-ray fluorescence spectrometer at Beijing Research Institute of Uranium Geology (China). Sample was firstly heated in a muffle furnace at $105^{\circ} \mathrm{C}$ for 4 hours, and then, anhydrous lithium tetraborate $(\sim 5.2 \mathrm{~g})$, lithium fluoride $(\sim 0.4 \mathrm{~g})$, and ammonium nitrate $(\sim 0.3 \mathrm{~g})$ were added to dissolve at $1150^{\circ} \mathrm{C}$ for another 15 minutes, in order to measure major oxides and loss on ignition. To determine trace elements, powered samples $(\sim 25 \mathrm{mg})$ were dissolved in a mixture of hydrofluoric acid $(1 \mathrm{ml})$ and nitric acid $(0.5 \mathrm{ml})$ in a tightly sealed Teflon bomb at $185^{\circ} \mathrm{C}$ for 24 hours. The dissolved samples were diluted to $25 \mathrm{ml}$ in a clean bottle for trace element analyses using a Finnigan MAT high-resolution inductively coupled plasma mass spectrometer. The relatively analytical precision is better than $5.0 \%$. The detailed procedures and experimental parameters for major and trace element analyses are followed by the Chinese National Standard GB/T 14506-28-2010 and GB/T 14506-30-2010, respectively.

\section{Results}

4.1. Bulk Geochemical Characteristics. The results of TOC, S, and Rock-Eval pyrolysis are given in Table 1. All the samples have relatively low TOC values of $0.2-1.11 \%$ with an average of $0.45 \%$ ( $n=30)$, displaying less variability upward from the bottom of this profile (Figure 3). Pyrolysis parameters $S_{1}$ and $S_{2}$ can represent the hydrocarbon generation potential of the organic matter [43]. The PG $\left(S_{1}+S_{2}\right)$ and HI values are distinctly low, varying from 0.02 to $0.30 \mathrm{mg} \mathrm{HC/g}$ rock (average $=0.11 \mathrm{mg} \mathrm{HC} / \mathrm{g}$ rock), and 5.0 to $49.0 \mathrm{mg} \mathrm{HC} / \mathrm{g}$ TOC (average $=17.8 \mathrm{mg} \mathrm{HC} / \mathrm{g}$ TOC), respectively. For the kerogen types of organic matter, these samples are commonly dominated by type II kerogen and following type III kerogen, as evidenced by the bulk geochemical and biomarker parameters studied by Du et al. [23] and Wang et al. [25]. On the cross-plot of $S_{2}$ versus TOC (Figure 4) [44], the studied samples in Well DW1 are classified as the poor to fair-quality source rocks with mature characters (Figure 4). However, equivalent black mudstones of the M3 in other drilling wells (e.g., Yang1 and Fusha2) show relatively higher TOC, PG, and HI contents than those in Well DW1, which can be generally regarded as poor to good-quality source rocks (Figure 4) [23]. 
TABle 1: TOC, S, and Rock-Eval pyrolysis data of the M3 lacustrine mudstones in the Yecheng-Hetian Sag.

\begin{tabular}{|c|c|c|c|c|c|c|c|c|}
\hline Samples & Depth/m & TOC/\% & $\mathrm{S} / \%$ & TOC/S & $S_{1}(\mathrm{mg} \mathrm{HC} / \mathrm{g}$ rock $)$ & $S_{2}$ (mg HC/g rock) & PG (mg HC/g rock) & $\mathrm{HI}$ (mg HC/g TOC) \\
\hline DW1-06 & 82.25 & 0.48 & 0.13 & 3.46 & 0.02 & 0.04 & 0.06 & 8 \\
\hline DW1-08 & 89.15 & 0.31 & 0.10 & 3.18 & 0.03 & 0.03 & 0.06 & 10 \\
\hline DW1-09 & 93.05 & 0.24 & 0.09 & 3.64 & 0.02 & 0.05 & 0.07 & 21 \\
\hline DW1-10 & 94.45 & 0.59 & 0.10 & 3.78 & 0.01 & 0.18 & 0.19 & 31 \\
\hline DW1-11 & 97.65 & 0.32 & 0.08 & 4.52 & 0.01 & 0.02 & 0.03 & 6 \\
\hline DW1-12 & 99.75 & 0.39 & 0.32 & 1.19 & 0.01 & 0.02 & 0.03 & 5 \\
\hline DW1-13 & 103.15 & 0.53 & 0.09 & 4.44 & 0.02 & 0.04 & 0.06 & 8 \\
\hline DW1-14 & 108.25 & 0.40 & 0.30 & 1.30 & 0.01 & 0.07 & 0.08 & 17 \\
\hline DW1-15 & 112.15 & 0.27 & 0.11 & 3.49 & 0.01 & 0.05 & 0.06 & 18 \\
\hline DW1-16 & 113.55 & 0.44 & 0.16 & 2.46 & 0.01 & 0.05 & 0.06 & 11 \\
\hline DW1-17 & 119.90 & 0.67 & 0.62 & 0.63 & 0.01 & 0.25 & 0.26 & 37 \\
\hline DW1-18 & 123.00 & 0.35 & 0.09 & 4.50 & 0.06 & 0.06 & 0.12 & 17 \\
\hline DW1-19 & 125.65 & 0.57 & 0.15 & 2.69 & 0.02 & 0.07 & 0.09 & 12 \\
\hline DW1-20 & 130.00 & 0.28 & 0.08 & 5.31 & 0.01 & 0.04 & 0.05 & 14 \\
\hline DW1-21 & 133.55 & 1.11 & 0.88 & 0.47 & 0.02 & 0.27 & 0.29 & 24 \\
\hline DW1-22 & 137.55 & 0.70 & 0.65 & 0.65 & 0.02 & 0.14 & 0.16 & 20 \\
\hline DW1-23 & 139.90 & 0.30 & 0.07 & 5.75 & 0.01 & 0.03 & 0.04 & 10 \\
\hline DW1-24 & 142.30 & 0.45 & 0.18 & 2.47 & 0.06 & 0.19 & 0.25 & 43 \\
\hline DW1-25 & 147.00 & 0.73 & 0.07 & 6.08 & 0.03 & 0.17 & 0.20 & 23 \\
\hline DW1-26 & 149.10 & 0.27 & 0.08 & 5.71 & 0.01 & 0.03 & 0.04 & 11 \\
\hline DW1-27 & 152.35 & 0.20 & 0.20 & 2.30 & 0.01 & 0.03 & 0.04 & 15 \\
\hline DW1-28 & 156.80 & 0.47 & 0.09 & 4.91 & 0.04 & 0.10 & 0.14 & 21 \\
\hline DW1-29 & 158.55 & 0.36 & 0.08 & 6.00 & 0.00 & 0.02 & 0.02 & 6 \\
\hline DW1-31 & 162.35 & 0.74 & 0.15 & 3.11 & 0.06 & 0.11 & 0.17 & 15 \\
\hline DW1-32 & 165.60 & 0.33 & 0.08 & 6.26 & 0.01 & 0.03 & 0.04 & 9 \\
\hline DW1-33 & 169.25 & 0.59 & 0.36 & 1.39 & 0.01 & 0.29 & 0.30 & 49 \\
\hline DW1-35 & 175.85 & 0.26 & 0.08 & 6.08 & 0.01 & 0.03 & 0.04 & 11 \\
\hline DW1-37 & 181.85 & 0.20 & 0.08 & 6.27 & 0.01 & 0.03 & 0.04 & 15 \\
\hline DW1-38 & 184.75 & 0.39 & 0.09 & 6.04 & 0.01 & 0.03 & 0.04 & 8 \\
\hline DW1-45 & 222.40 & 0.59 & 0.43 & 3.22 & 0.03 & 0.24 & 0.27 & 40 \\
\hline
\end{tabular}

Abbreviations: TOC: total organic carbon; S: total sulfur; $S_{1}$ : free hydrocarbons; $S_{2}$ : hydrocarbons generated; PG: potential generation index; $S_{1}+S_{2}$; HI: hydrocarbon index, $S_{2} \times 100 /$ TOC.

Moreover, the $\mathrm{S}$ contents of these lacustrine mudstones range from $0.07 \%$ to $0.88 \%$ with a median of $0.20 \%$. The $\mathrm{TOC} / \mathrm{S}$ ratios, which reflect the vertical changes in paleosalinity during the deposition $[45,46]$, are lower than 10.0 , varying between 1.01 and 9.97 .

4.2. Major Elements. Major element concentrations of the studied lacustrine mudstones are listed in Table 2. $\mathrm{SiO}_{2}$, $\mathrm{Al}_{2} \mathrm{O}_{3}$, and $\mathrm{CaO}$ are the predominant oxides, with their contents ranging from $36.93 \%$ to $55.45 \%, 10.31 \%$ to $16.32 \%$, and $4.44 \%$ to $16.35 \%$, respectively. The second abundant oxides are the $\mathrm{TFe}_{2} \mathrm{O}_{3}$ (3.66-6.419\%), $\mathrm{MgO}(2.51-5.37 \%), \mathrm{K}_{2} \mathrm{O}$ (1.92-3.32\%), and $\mathrm{Na}_{2} \mathrm{O}$ (1.07-2.77\%), while contents of other oxides (e.g., $\mathrm{TiO}_{2}, \mathrm{P}_{2} \mathrm{O}_{5}$, and $\mathrm{MnO}$ ) are generally lower than $1.0 \%$. When normalized to the Post-Archaean Australia Shale (PAAS) [47], these samples show uniform distribution patterns (Figure 5(a)). The contents of $\mathrm{CaO}, \mathrm{MgO}$, and $\mathrm{Na}_{2} \mathrm{O}$ are strongly enriched, whereas others, such as the $\mathrm{SiO}_{2}$,
$\mathrm{Al}_{2} \mathrm{O}_{3}, \mathrm{MnO}, \mathrm{K}_{2} \mathrm{O}, \mathrm{TiO}_{2}, \mathrm{TFe}_{2} \mathrm{O}_{3}$, and $\mathrm{P}_{2} \mathrm{O}_{5}$, are substantially depleted relative to those of the PAAS. In the well, these major element compositions in each sample are relatively uniform and exhibit slight vertical fluctuations.

4.3. Trace Elements. Some specific trace element concentrations of the studied samples are shown in Table 3. In the descending order of average concentration, trace elements include Sr ( 519 ppm), Ba ( 346 ppm), B ( 147 ppm), Zr $(\sim 128 \mathrm{ppm}), \quad \mathrm{Rb} \quad(\sim 112 \mathrm{ppm}), \quad \mathrm{V} \quad(\sim 90.9 \mathrm{ppm}), \quad \mathrm{Zn}$ $(\sim 78.4 \mathrm{ppm}), \quad \mathrm{Cr} \quad(\sim 69.2 \mathrm{ppm}), \quad \mathrm{Ni} \quad(\sim 41.3 \mathrm{ppm}), \quad \mathrm{Cu}$ $(\sim 28.4 \mathrm{ppm}), \quad$ Co $\quad(\sim 14.9 \mathrm{ppm}), \quad$ Sc $(\sim 12 \mathrm{ppm}), \quad$ Th $(\sim 9.91 \mathrm{ppm})$, Hf $(\sim 3.91 \mathrm{ppm}), \mathrm{U}(\sim 3.51 \mathrm{ppm})$, and Mo $(\sim 0.76 \mathrm{ppm})$. Vertically, these trace elements do not also display distinctive changing trends along with the depths in the profile. Enrichment factor (EF) has been used to characterize the relative enrichment degree of trace elements [19]. Aluminium $(\mathrm{Al})$ is often used as a normalized element due to 


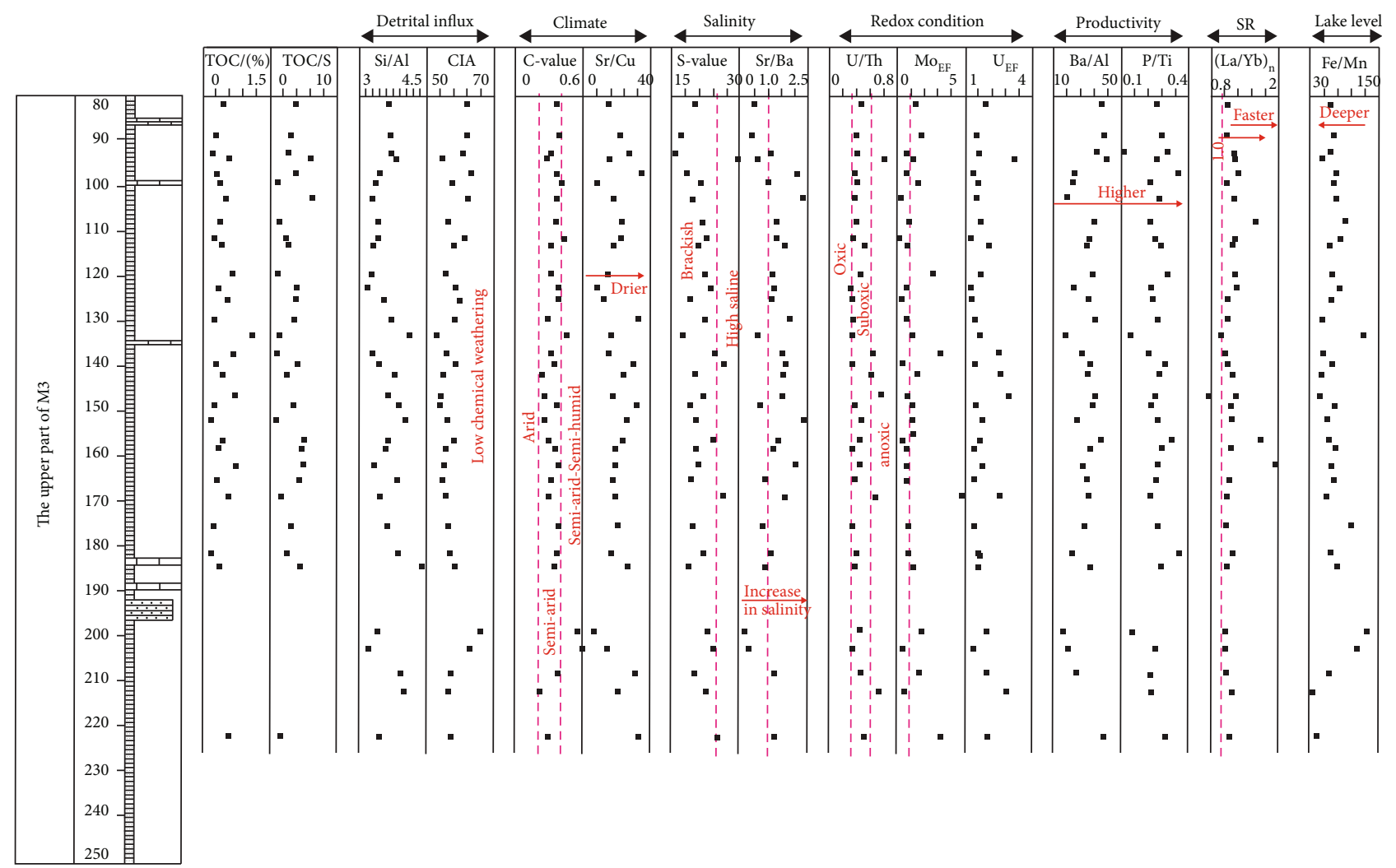

$\because$ Sandstone

-- Mudstone

巴⿴囗十 Limestone

FIGURE 3: Stratigraphic variations of TOC contents, TOC/S ratio, and geochemical proxies of detrital influx, climate, salinity, redox condition, productivity, sedimentation rate (SR), and paleowater depth for these M3 mudstones in Well DW1.

its relatively high abundance and stability during weathering, transportation, and diagenesis. $\mathrm{EF}_{\text {element }}$ was calculated using the following equation:

$\mathrm{EF}_{\text {element }}=(\text { element } / \mathrm{Al})_{\text {sample/ }}(\text { element } / \mathrm{Al})_{\text {background }}$,

where the background values refer to those of PAAS in the present study [47]. EF $<1.0$ indicates a depletion, whereas EF $>1.0$ or greater corresponds to a distinct enrichment relative to the PAAS. The EF results are shown in Figure 5(b), showing enrichment or depletion of trace elements with varying degrees. Remarkably, $\mathrm{Sr}$ is strongly enriched, with EF values varying from 2.72 to 7.5 . In contrast, other trace elements, such as $\mathrm{B}(\mathrm{EF}=1.8-2.93), \mathrm{Zn}(\mathrm{EF}=1.01$ $2.08), \mathrm{U}(\mathrm{EF}=1.14-3.15), \mathrm{Hf}(\mathrm{EF}=1.06-1.64), \mathrm{Ni}(\mathrm{EF}=0.78-$ 1.53), Sc $\quad(\mathrm{EF}=1.07-1.38), \quad \mathrm{Th} \quad(\mathrm{EF}=0.97-1.32), \quad \mathrm{Rb}$ $(\mathrm{EF}=0.91-1.34), \mathrm{Co}(\mathrm{EF}=0.7-1.83), \mathrm{Cr}(\mathrm{EF}=0.82-1.35), \mathrm{V}$ $(\mathrm{EF}=0.71-1.13), \mathrm{Zr} \quad(\mathrm{EF}=0.79-1.27), \mathrm{Cu} \quad(\mathrm{EF}=0.39-1.57)$, and $\mathrm{Ba}(\mathrm{EF}=0.46-1.2)$, show roughly narrow $\mathrm{EF}$ values being close to 1.0, suggesting slight enrichment or depletion. However, Mo element exhibits a wide range of EF values (0.27-5.0), which indicates various degrees of depletion to enrichment.

Total REE ( $\sum \mathrm{REE}$ ) contents range between $116.3 \mathrm{ppm}$ and $201.3 \mathrm{ppm}$ (Table 4), with an average of $134.8 \mathrm{ppm}$. However, most of the $\sum$ REE concentrations are not above
$150 \mathrm{ppm}$, lower than that of PAAS (183.0 ppm) [47]. ¿REE contents are positively correlated with $\mathrm{Al}_{2} \mathrm{O}_{3}$ (Figure 6(a)), suggesting typical detrital sources that were not affected by chemical alteration and sedimentary sorting. The $\sum \mathrm{LREE} / \sum \mathrm{HREE}(\mathrm{L} / \mathrm{H})$ ratio varies from 7.4 to 12.5 , reflecting a moderate enrichment in LREE relative to HREE. When normalized to the chondrite (Figure 7) [48], samples are characterized by fractionated LREE patterns $\left[(\mathrm{La} / \mathrm{Sm})_{\mathrm{N}}=3.91\right.$ on average $]$, flat HREE patterns $\left[(\mathrm{Gd} / \mathrm{Yb})_{\mathrm{N}}=1.37\right]$, obvious Eu negative anomalies $\left(\mathrm{Eu} / \mathrm{Eu}^{*}\right.$ $=0.61-0.7)$, and weak Ce negative anomalies $\left(\mathrm{Ce} / \mathrm{Ce}^{*}\right.$ $=0.92-0.97$ ).

\section{Discussion}

5.1. Sedimentary Recycling and Diagenesis. Sedimentary recycling and diagenesis can affect the redistribution of major and trace elements in sediments [49, 50]. Index of Compositional Variability $\left[\mathrm{ICV}=\left(\mathrm{CaO}+\mathrm{Na}_{2} \mathrm{O}+\mathrm{K}_{2} \mathrm{O}\right.\right.$ $\left.+\mathrm{TFe}_{2} \mathrm{O}_{3}+\mathrm{MgO}+\mathrm{MnO}+\mathrm{TiO}_{2}\right) / \mathrm{Al}_{2} \mathrm{O}_{3}$, all in weight percentages (\%)] was defined as an index to evaluate the recycling process and compositional maturity of rocks [50]. An ICV value > 1.0 indicates that sediments were likely sourced from the first-cycle materials in active 


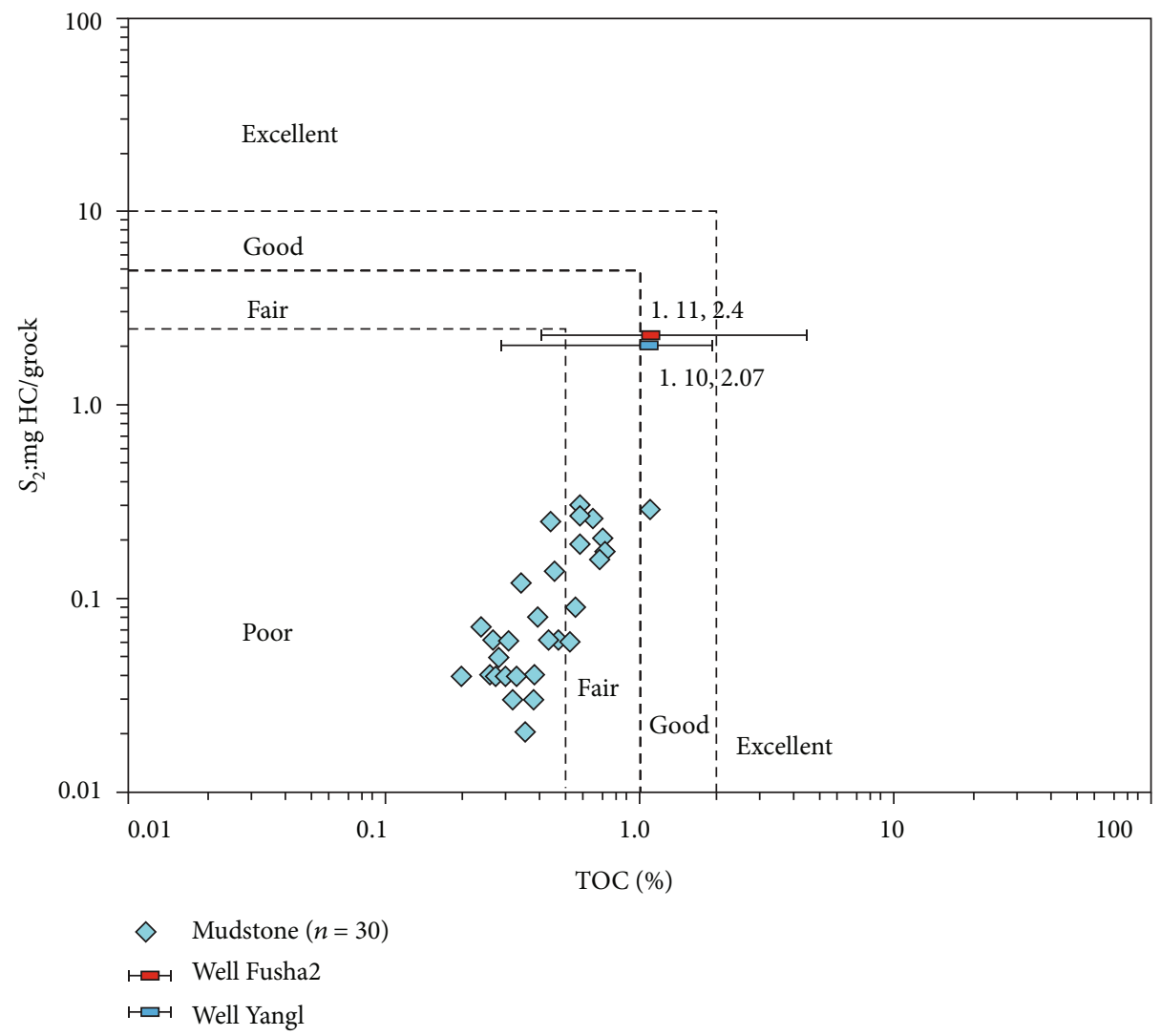

Figure 4: Cross-plot of TOC versus pyrolysis $\mathrm{S}_{2}$ for the M3 mudstones in Well DW1 within the Yecheng-Hetian Sag, showing poor- to fairquality hydrocarbon generation potential [44].

tectonic settings with a low degree of sediment recycling, while an ICV value $<1.0$ is suggestive of either recycled weathered materials in cratonic environments or firstcycle products but enhanced by intense weathering. All the studied samples except for DW1-41 have high ICV values from 1.21 to 2.17 , which implies that they are compositionally immature, and received first-recycling detrital materials in an active tectonic setting.

Moreover, cross-plot of $\mathrm{Th} / \mathrm{Sc}$ against $\mathrm{Zr} / \mathrm{Sc}$ ratios is widely used to constrain the degree of recycling and sorting [49]. The $\mathrm{Th} / \mathrm{Sc}$ and $\mathrm{Zr} / \mathrm{Sc}$ ratios of the samples vary between 0.74 and 1.12 averaging 0.82 and between 8.99 and 15.49 averaging 10.64 (Table 2). These data were plotted away from the trending line of mineral sorting and recycling (Figure 8(a)). Similarly, the $\mathrm{Al}_{2} \mathrm{O}_{3}-\left(\mathrm{CaO}^{*}+\mathrm{Na}_{2} \mathrm{O}\right)-\mathrm{K}_{2} \mathrm{O}$ (A$\mathrm{CN}-\mathrm{K}$; all in molar percentages) ternary diagram can also be applied to deduce the postdepositional diagenetic and metasomatic processes and parental rock composition [5153]. On the A-CN-K diagram (Figure 8(b)), all the samples plot above the plagioclase-potash feldspar joint, and fall between the granodioritic and granitic rocks. The predicted weathering trend of these studied samples is subparallel to the A-CN boundary and does not display any implication toward the $\mathrm{K}_{2} \mathrm{O}$ apex, revealing insignificant potashmetasomatism during burial diagenesis.

Furthermore, although REEs in sediments are generally not easily mobile during weathering and transportation, diagenetic exchanges after the depositions would cause the apparent enrichment of $\mathrm{Ce}$, depletion of $\mathrm{Eu}$, and decrease in $(\mathrm{Dy} / \mathrm{Sm})_{\mathrm{N}}$ ratio [54]. Negative correlations between $\mathrm{Ce} / \mathrm{Ce}^{*}$ and $\mathrm{Eu} / \mathrm{Eu}^{*}$ or $(\mathrm{Dy} / \mathrm{Sm})_{\mathrm{N}}$ may be the result of diagenetic alterations. However, no detectable negative covariations between the $\mathrm{Ce} / \mathrm{Ce} *$ and $\mathrm{Eu} / \mathrm{Eu}^{*}$ and $(\mathrm{Dy} / \mathrm{Sm})_{\mathrm{N}}$ ratio are observed in these lacustrine mudstones (Table 4), suggesting minor secondary chemical alterations.

In summary, the geochemical data of lacustrine mudstones, to a large extent, represent their original chemical compositions of the source rocks and could be used to identify their provenance, paleoclimate, and water conditions as the following texts.

5.2. Provenance and Tectonic Setting. Geochemical data of fine-grained sediments have been widely employed to investigate the source-rock lithotypes and their tectonic settings, due to their robust chemical behaviors during weathering, transportation, and diagenesis [55-62]. The ratios of $\mathrm{Al}_{2} \mathrm{O}_{3} /-$ $\mathrm{TiO}_{2}(\mathrm{Al} / \mathrm{Ti})$ and $\mathrm{TiO}_{2} / \mathrm{Zr}(\mathrm{Ti} / \mathrm{Zr})$ are often invariable and represent the chemical compositions of their parental rocks [61]. Al/Ti ratios $>21$ and $\mathrm{Ti} / \mathrm{Zr}$ ratios $<55$ are indicative of felsic rocks, whereas mafic rocks have $\mathrm{Al} / \mathrm{Ti}$ ratios lower than 8 and Ti/Zr ratios more than 200. For the studied samples, $\mathrm{Al} / \mathrm{Ti}$ and Ti/Zr values range from 21 to 25 and 35 to 49 , respectively, indicating a relatively stable provenance supply that consists principally of felsic rocks (Figures 9(a) and 9(b)). The above interpretation is inferred in the A-CN-K and $\mathrm{Zr} / \mathrm{Sc}$ versus $\mathrm{Th} / \mathrm{Sc}$ diagrams, in which provenance was 
TABLe 2: Major element concentrations (as \%) for the M3 lacustrine mudstones in the Yecheng-Hetian Sag.

\begin{tabular}{|c|c|c|c|c|c|c|c|c|c|c|c|c|c|c|c|c|}
\hline Samples & Depth/m & $\mathrm{SiO}_{2} / \%$ & $\begin{array}{c}\mathrm{TiO}_{2} \\
1 \%\end{array}$ & $\begin{array}{c}\mathrm{Al}_{2} \mathrm{O}_{3} \\
/ \%\end{array}$ & $\begin{array}{c}\mathrm{MnO} \\
/ \%\end{array}$ & $\begin{array}{c}\mathrm{MgO} \\
/ \%\end{array}$ & $\mathrm{CaO} / \%$ & $\begin{array}{c}\mathrm{Na}_{2} \mathrm{O} \\
/ \%\end{array}$ & $\mathrm{~K}_{2} \mathrm{O} / \%$ & $\mathrm{P}_{2} \mathrm{O}_{5} / \%$ & $\begin{array}{c}\mathrm{TFe}_{2} \mathrm{O}_{3} \\
/ \%\end{array}$ & $\mathrm{Ti} / \mathrm{Al}$ & CIA & ICV & $\mathrm{P} / \mathrm{Ti}$ & $\mathrm{Ba} / \mathrm{Al}$ \\
\hline DW1-06 & 82.25 & 41.33 & 0.51 & 11.29 & 0.08 & 5.29 & 12.85 & 1.17 & 2.88 & 0.13 & 5.33 & 0.045 & 61.8 & 1.83 & 0.26 & 39.06 \\
\hline DW1-08 & 89.15 & 43.36 & 0.53 & 11.74 & 0.08 & 5.01 & 12.32 & 1.27 & 2.83 & 0.15 & 5.52 & 0.045 & 61.8 & 1.75 & 0.28 & 38.93 \\
\hline DW1-09 & 93.05 & 39.69 & 0.49 & 10.68 & 0.08 & 4.70 & 14.99 & 1.16 & 2.80 & 0.15 & 5.18 & 0.046 & 60.9 & 2.14 & 0.31 & 34.83 \\
\hline DW1-10 & 94.45 & 39.19 & 0.49 & 10.31 & 0.09 & 5.30 & 15.18 & 1.92 & 2.05 & 0.13 & 4.61 & 0.048 & 54.7 & 2.16 & 0.26 & 41.32 \\
\hline DW1-11 & 97.65 & 40.18 & 0.49 & 11.66 & 0.07 & 5.23 & 13.82 & 1.07 & 3.07 & 0.17 & 5.57 & 0.042 & 63.0 & 1.89 & 0.35 & 22.30 \\
\hline DW1-12 & 99.75 & 44.79 & 0.56 & 13.25 & 0.07 & 4.71 & 10.36 & 2.14 & 2.54 & 0.13 & 5.22 & 0.043 & 57.5 & 1.43 & 0.23 & 21.89 \\
\hline DW1-13 & 103.15 & 40.42 & 0.51 & 12.18 & 0.08 & 5.00 & 13.32 & 1.21 & 3.09 & 0.14 & 5.55 & 0.042 & 62.4 & 1.79 & 0.27 & 18.14 \\
\hline DW1-14 & 108.25 & 46.18 & 0.59 & 13.54 & 0.06 & 3.74 & 10.97 & 2.43 & 2.31 & 0.13 & 5.03 & 0.043 & 56.3 & 1.47 & 0.23 & 34.05 \\
\hline DW1-15 & 112.15 & 42.44 & 0.53 & 12.46 & 0.07 & 5.36 & 12.19 & 1.58 & 2.51 & 0.13 & 5.92 & 0.042 & 61.1 & 1.66 & 0.25 & 30.74 \\
\hline DW1-16 & 113.55 & 40.38 & 0.51 & 12.18 & 0.08 & 5.09 & 13.60 & 1.89 & 2.36 & & 5.01 & 0.042 & 58.1 & 1.76 & 0.27 & 30.05 \\
\hline DW1-17 & 119.90 & 43.49 & 0.53 & 13.27 & 0.07 & 3.76 & 12.32 & 2.42 & 2.39 & & 4.93 & 0.040 & 55.7 & 1.59 & 0.30 & 32.63 \\
\hline DW1-18 & 123.00 & 42.95 & 0.54 & 13.52 & 0.07 & 4.16 & 11.36 & 1.97 & 2.84 & 0.13 & 5.27 & 0.040 & 58.6 & 1.51 & 0.23 & 22.12 \\
\hline DW1-19 & 125.65 & 42.25 & 0.52 & 11.83 & 0.08 & 5.37 & 12.64 & 1.62 & 2.45 & 0.12 & 5.52 & 0.044 & 59.7 & 1.75 & 0.24 & 30.77 \\
\hline DW1-20 & 130.00 & 39.70 & 0.49 & 10.67 & 0.09 & 5.23 & 15.27 & 1.53 & 2.46 & 0.13 & 4.70 & 0.046 & 58.1 & 2.10 & 0.26 & 35.24 \\
\hline DW1-21 & 133.55 & 55.20 & 0.65 & 13.43 & 0.04 & 2.61 & 74 & 2.77 & 2.58 & 0.09 & 4.89 & 0.049 & 53.0 & 1.24 & 0.14 & 17.05 \\
\hline DW1-22 & 137.55 & 41.03 & 0.54 & 12.44 & 0.09 & 5.24 & 13.04 & 2.22 & 2.30 & 0.12 & 4.73 & 0.043 & 55.9 & 1.67 & 0.22 & 26.61 \\
\hline DW1-23 & 139.90 & 39.88 & 0.49 & 11.54 & 0.08 & 5.37 & 13.84 & 1.61 & 2.63 & 0.14 & 5.32 & 0.042 & 58.6 & 1.89 & 0.29 & 31.20 \\
\hline DW1-24 & 142.30 & 40.60 & 0.49 & 10.65 & 0.09 & 4.56 & 15.92 & 2.00 & 1.92 & 0.13 & 4.20 & 0.046 & 55.1 & 2.14 & 0.27 & 30.99 \\
\hline DW1-25 & 147.00 & 39.27 & 0.49 & 10.73 & 0.10 & 4.92 & 15.40 & 2.07 & 2.05 & 0.12 & 4.34 & 0.045 & 54.3 & 2.09 & 0.25 & 34.76 \\
\hline DW1-26 & 149.10 & 43.62 & 0.54 & 11.21 & 0.08 & 4.57 & 12.90 & 2.02 & 2.69 & 0.13 & 5.60 & 0.049 & 54.0 & 1.96 & 0.23 & 33.45 \\
\hline DW1-27 & 152.35 & 42.99 & 0.49 & 10.68 & 0.07 & 4.47 & 14.70 & 1.75 & 2.35 & 0.13 & 4.35 & 0.046 & 56.2 & 2.05 & 0.26 & 24.06 \\
\hline DW1-28 & 156.80 & 40.43 & 0.50 & 11.01 & 0.08 & 5.15 & 14.68 & 1.62 & 2.39 & 0.16 & 4.81 & 0.045 & 58.2 & 2.00 & 0.32 & 37.33 \\
\hline DW1-29 & 158.55 & 42.14 & 0.52 & 11.66 & 0.07 & 4.57 & & 1.94 & 2.81 & 0.15 & 5.43 & 0.045 & 55.3 & 1.85 & 0.28 & 31.99 \\
\hline DW1-31 & 162.35 & 42.07 & 0.54 & 12.68 & 0.08 & 5.15 & & 2.32 & 2.45 & 0.14 & 5.20 & 0.042 & 55.2 & 1.60 & 0.26 & 27.68 \\
\hline DW1-32 & 165.60 & & 0.53 & 11.52 & 0.07 & 4.05 & & 2.02 & & & 5.03 & 0.046 & 55.1 & 1.85 & 0.25 & 29.69 \\
\hline DW1-33 & 169.25 & 39.77 & 0.52 & 11.54 & 0.08 & 5.24 & & 2.05 & 2.21 & & 4.82 & 0.045 & 55.8 & 1.92 & 0.23 & 30.94 \\
\hline DW1-35 & 175.85 & 46.41 & 0.55 & 12.86 & 0.05 & 3.50 & 10.75 & 2.09 & 2.95 & 0.14 & 5.27 & 0.043 & 56.1 & 1.58 & 0.26 & 28.15 \\
\hline DW1-37 & 181.85 & 45.30 & 0.53 & 11.71 & 0.08 & 4.22 & 11.71 & 1.80 & 2.75 & 0.19 & 5.48 & 0.045 & 56.8 & 1.76 & 0.36 & 21.09 \\
\hline DW1-38 & 184.75 & 47.46 & 0.52 & 10.82 & 0.07 & 3.63 & 12.73 & 1.59 & 2.32 & 0.14 & 5.03 & 0.048 & 58.3 & 1.92 & 0.27 & 30.59 \\
\hline DW1-41 & 199.20 & 55.45 & 0.68 & 16.32 & 0.04 & 2.51 & 4.44 & 2.31 & 2.92 & 0.10 & 4.71 & 0.042 & 66.0 & 0.86 & 0.15 & 15.69 \\
\hline DW1-42 & 203.00 & 48.45 & 0.63 & 15.13 & 0.06 & 3.49 & 7.54 & 1.64 & 3.32 & 0.16 & 6.49 & 0.042 & 62.7 & 1.21 & 0.25 & 18.70 \\
\hline DW1-43 & 208.50 & 45.75 & 0.56 & 11.66 & 0.09 & 3.57 & 12.24 & 1.81 & 2.54 & 0.13 & 5.51 & 0.048 & 57.2 & 1.83 & 0.23 & 23.33 \\
\hline DW1-44 & 212.65 & 42.72 & 0.52 & 10.71 & 0.11 & 3.46 & 16.21 & 1.81 & 2.11 & 0.12 & 3.66 & 0.048 & 56.5 & 2.15 & 0.23 & - \\
\hline DW1-45 & 222.40 & 36.93 & 0.46 & 10.78 & 0.12 & 5.28 & 16.35 & 1.77 & 2.09 & 0.13 & 4.72 & 0.043 & 57.1 & 2.17 & 0.29 & 39.70 \\
\hline
\end{tabular}

Abbreviation: “-” means invalid data.

mainly composed of the granodioritic and granitic rocks (Figure 8).

Other binary diagrams, such as $\mathrm{La} / \mathrm{Sc}$ versus $\mathrm{Co} / \mathrm{Th}$ and Hf versus La/Th, are also used to evaluate the source-rock compositions $[59,62,63]$. In the present study, these immobile elements show strong positive relationships with terrigenous $\mathrm{Al}_{2} \mathrm{O}_{3}$ and $\mathrm{TiO}_{2}$ (Tables 2 and 3), preserving useful geochemical information of the parental rocks. Most of the studied samples are plotted within the felsic fields but possibly mixed with minor intermediate rocks and old sediments (Figures 9(c) and 9(d)). Typically, sediments derived from the felsic provenance are characterized by relatively low $\sum$ REE contents, strong fractionated REE, and distinct negative $\mathrm{Eu}$ anomalies, whereas contradict REE features are always indicative of the mafic rocks $[59,64]$. The chondrite-normalized patterns further support a predominant felsic provenance with distinctive negative $\mathrm{Eu}$ anomalies $\left(\mathrm{Eu} / \mathrm{Eu}^{*}=0.61 \sim 0.7\right.$; Table 4$)$.

To further constrain the tectonic setting of source rocks, several discrimination diagrams were used in this study [56, $57,65]$. For example, on the cross-plot of $\mathrm{K}_{2} \mathrm{O} / \mathrm{Na}_{2} \mathrm{O}$ versus $\mathrm{SiO}_{2} / \mathrm{Al}_{2} \mathrm{O}_{3}$, these samples are scattered into the fields of active continental margin (ACM) and continental island arc (CIA) (Figure 10(a)). Further, the ternary discrimination diagrams of La-Th-Sc, Th-Sc-Zr/10, and Th-Co-Zr/10 were applied to decipher the tectonic settings [57]. Almost all the samples fall within the field of continental island arc (CIA) but adjacent to the ACM area (Figures 10(b)-10(d)). 


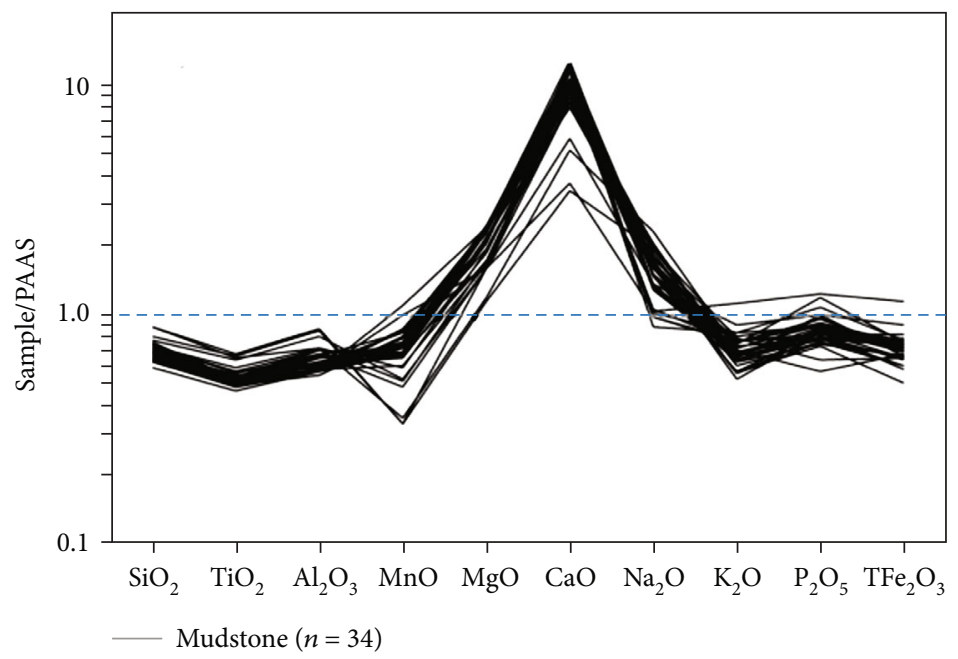

(a)

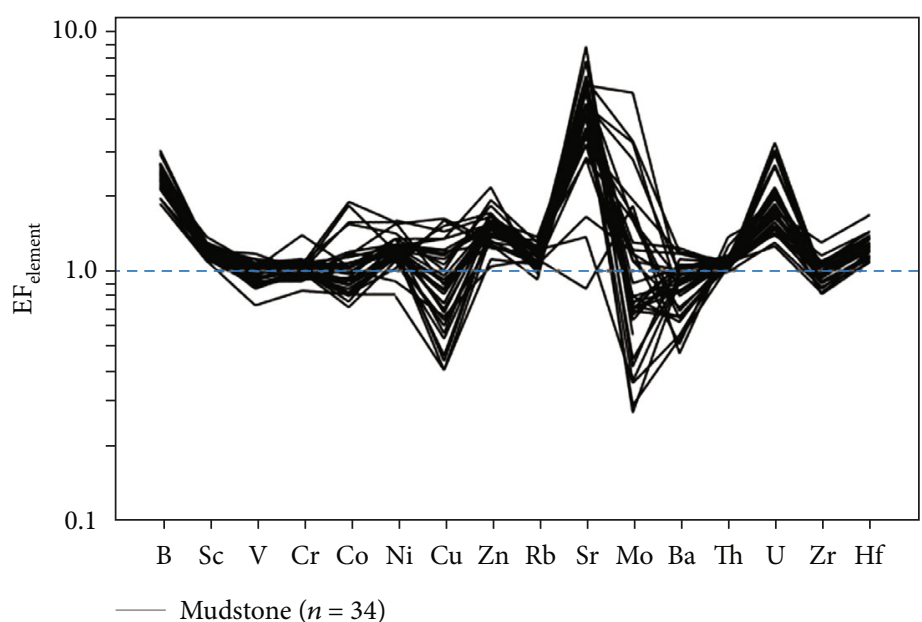

(b)

Figure 5: The Post-Archean Australian Shale- (PAAS-; Taylor and McLennan, [47]) normalized patterns of major elements (a) and enrichment factor (EF; b) of some selected trace elements for the M3 mudstones in Well DW1.

Moreover, according to the criteria of Bhatia [56], the contents of $\mathrm{La}, \mathrm{Ce}, \mathrm{REE},(\mathrm{La} / \mathrm{Yb})_{\mathrm{N}}$, and $\mathrm{Eu} / \mathrm{Eu} *($ Table 4$)$ of the studied samples are much more similar with the continental island arc (dissected magmatic arc) than the ACM tectonic setting.

Paleocurrent data indicate that the provenance during the deposition of the Pusige Formation was the West Kunlun Orogen located on the southwest of the study area [34]. The above results have indicated that the study area received detritus from a predominant felsic provenance consisting of granodiorite and granite with continental island arc-related tectonic signatures. By coincidence, previous studies have reported that large-scale Paleozoic granodiorite and granite are widely distributed within the West Kunlun Orogen (Figure 1(b)), which were formed under continental island arc (mostly) and active continental margin-related tectonic settings [35-39]. Chondrite-normalized REE patterns of some Paleozoic felsic plutons from the Kudi, Mazha, and Kangxiwar regions to the southwest of the study area can be compared with those of lacustrine mudstones (Figure 7)
[35-39]. Thus, it is credible that the dominant provenance for the study area during the Permian was the West Kunlun Orogen to the southwest.

5.3. Paleoweathering and Paleoclimate Implications. Chemical Index of Alteration (CIA) is commonly employed to quantitatively evaluate the paleoweathering conditions [49, 51-53] and calculated using the following equation:

$$
\mathrm{CIA}=\left[\mathrm{Al}_{2} \mathrm{O}_{3} /\left(\mathrm{Al}_{2} \mathrm{O}_{3}+\mathrm{CaO}^{*}+\mathrm{Na}_{2} \mathrm{O}+\mathrm{K}_{2} \mathrm{O}\right)\right] \times 100,
$$

where all elements are presented as molar ratios, of which $\mathrm{CaO}^{*}$ only represents silicate minerals (excluding calcite, dolomite, and apatite), and is calibrated using the method of McLennan et al. [49]. As discussed in Section 5.1, none of the studied samples were not influenced by sedimentary sorting, recycling, and diagenesis, and thus, CIA values are credible to examine the chemical weathering intensity in the study area. CIA values of the studied samples range between 53.0 and 66.0 with an average of 57.9 (Table 2), 


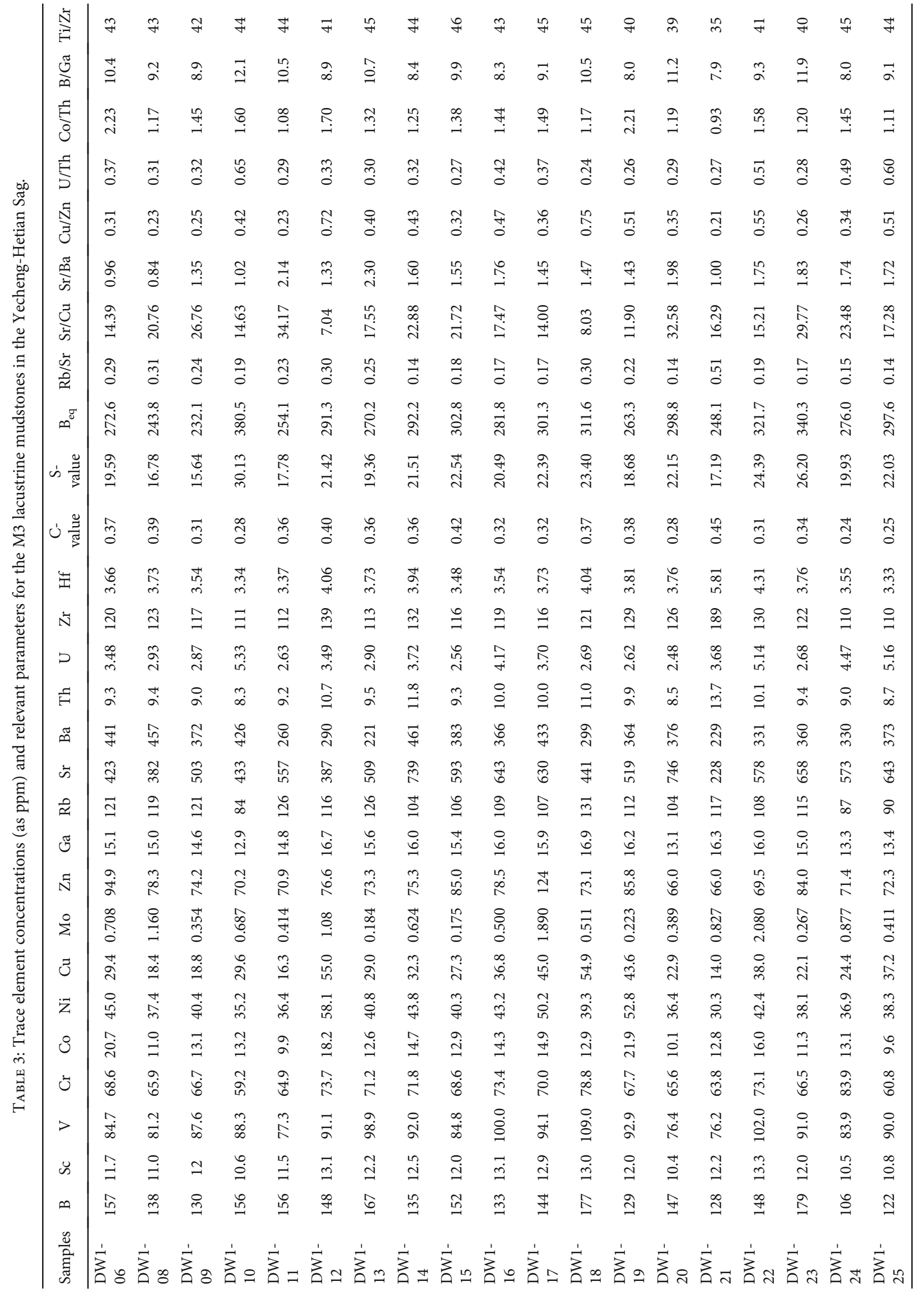




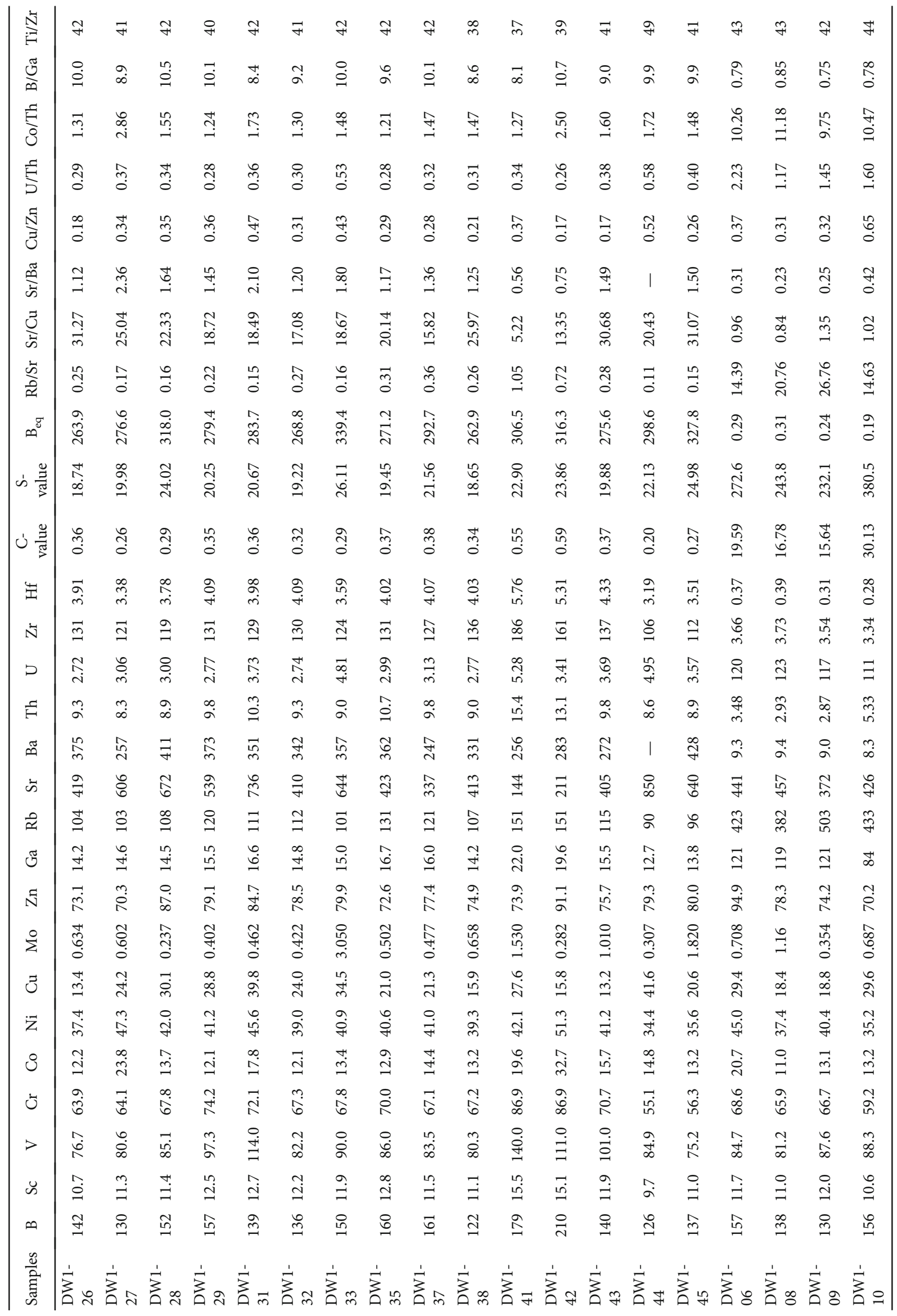




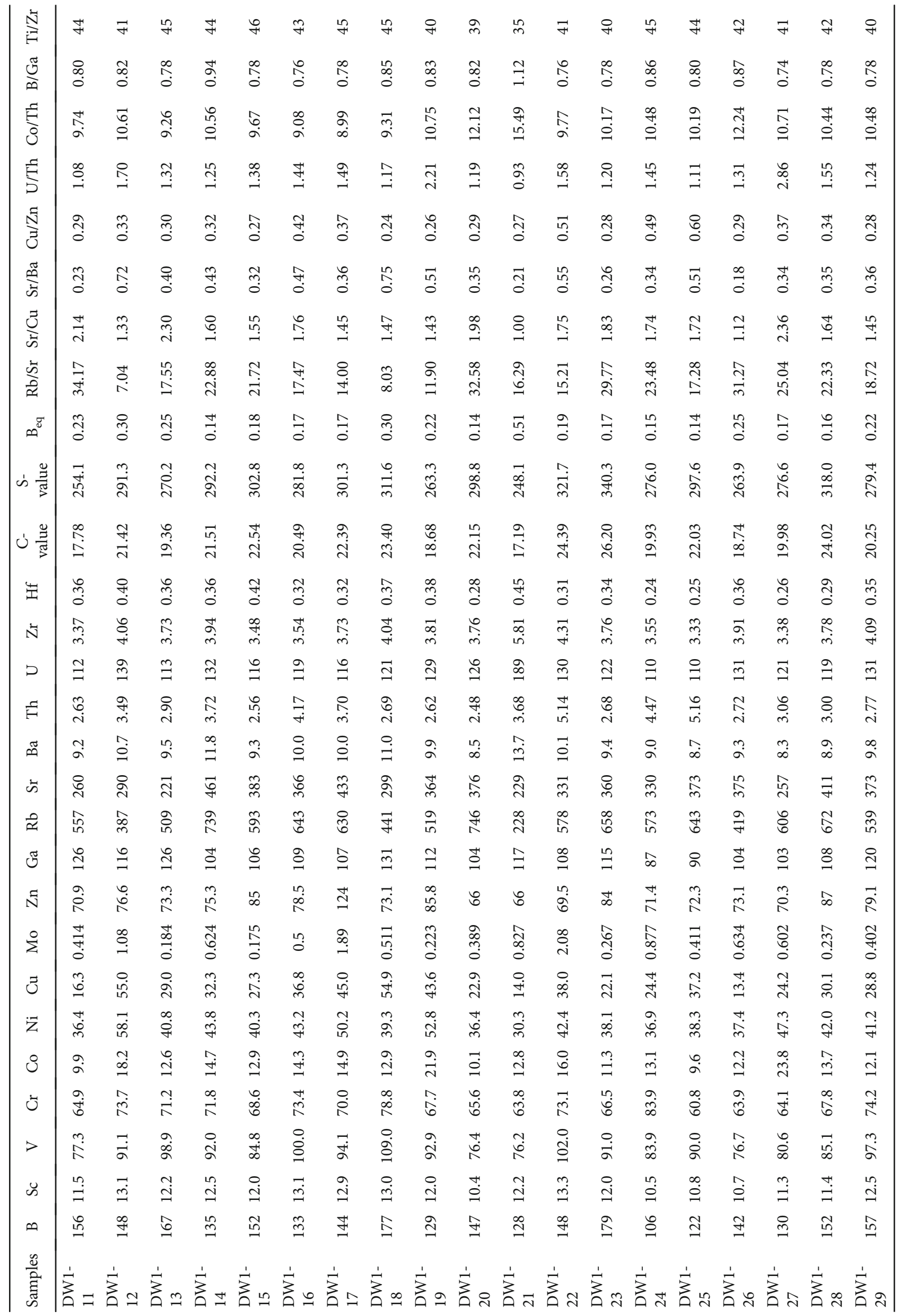




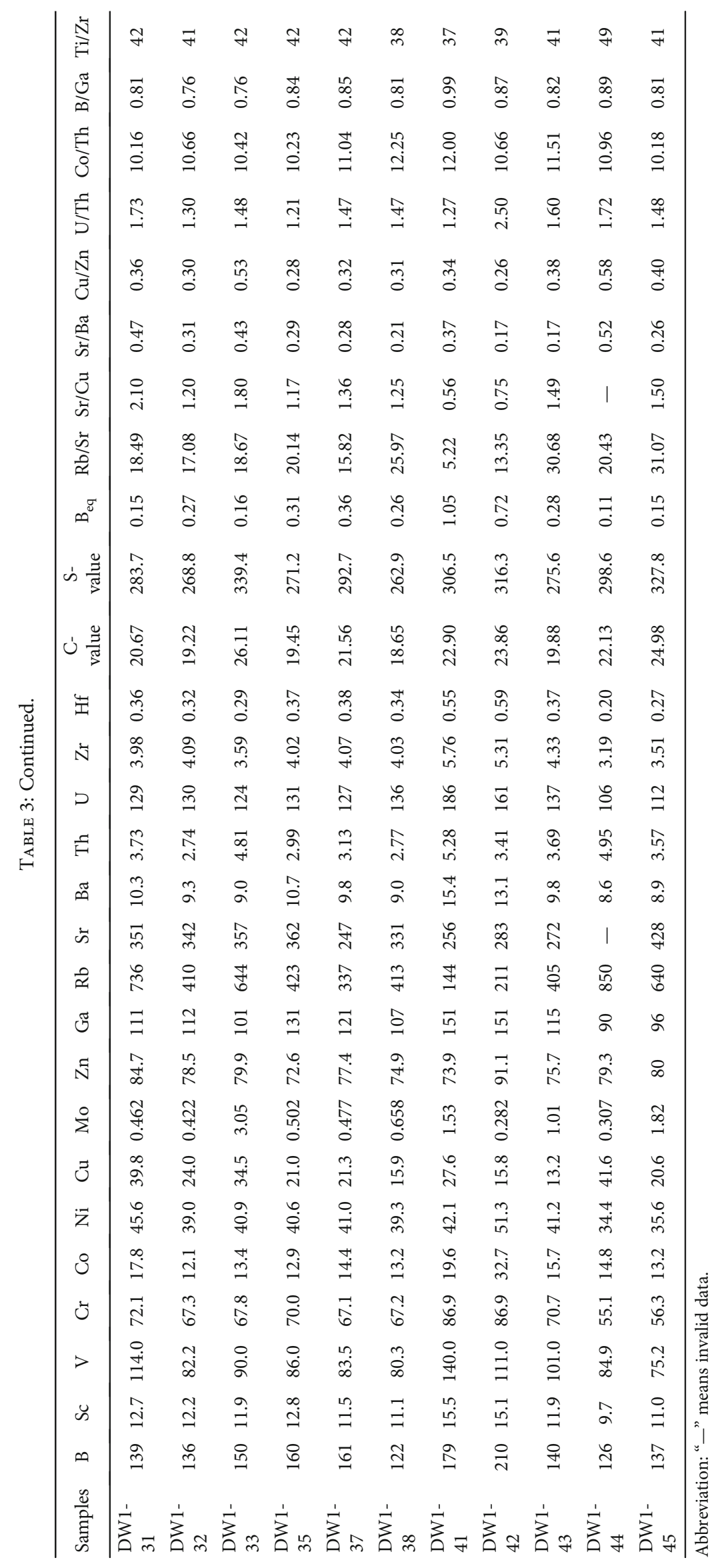




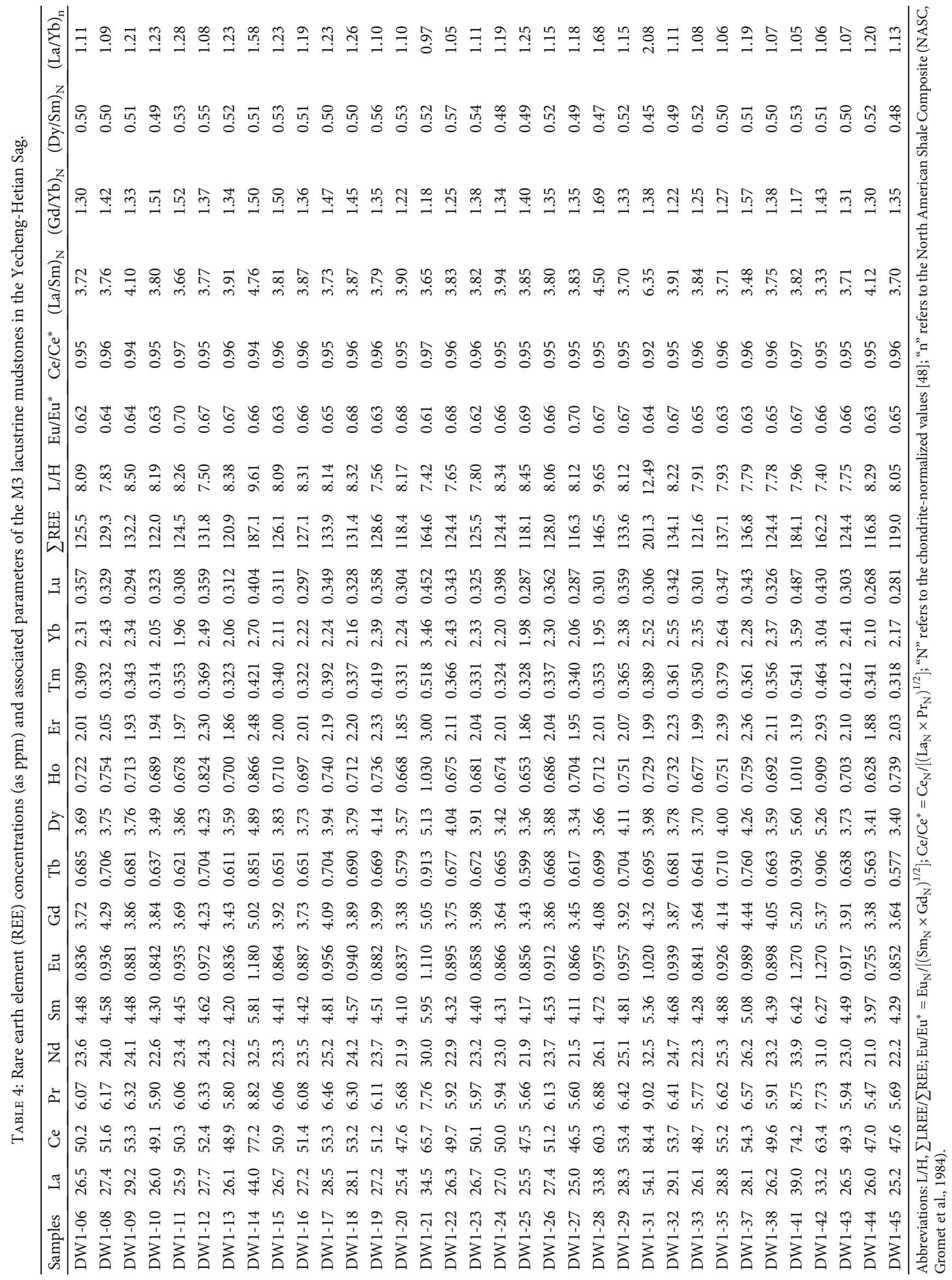




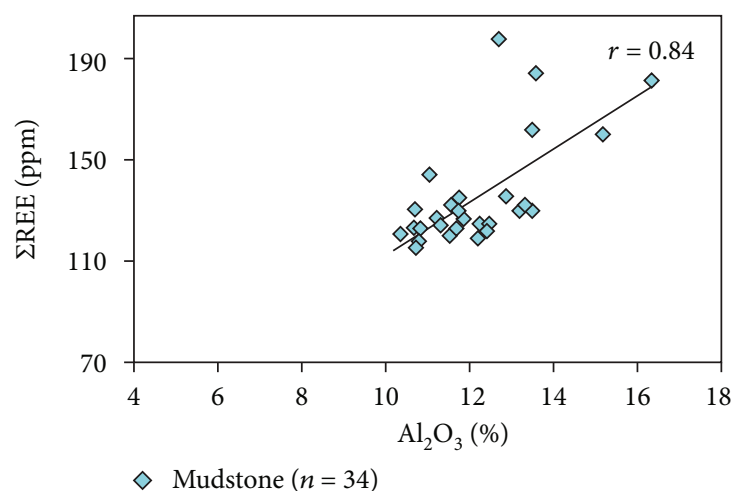

(a)

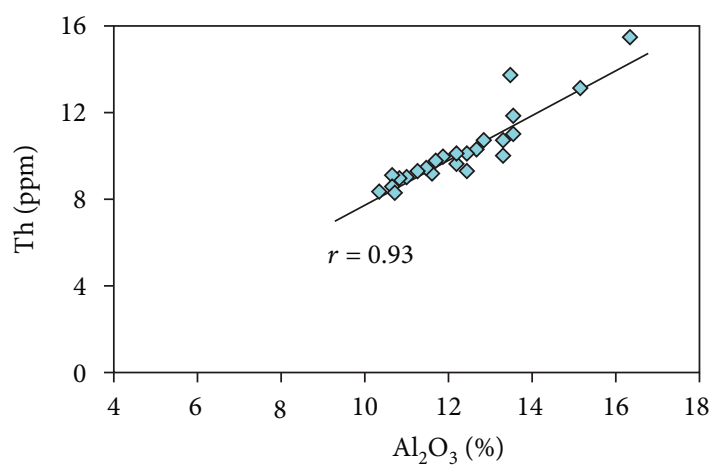

(c)

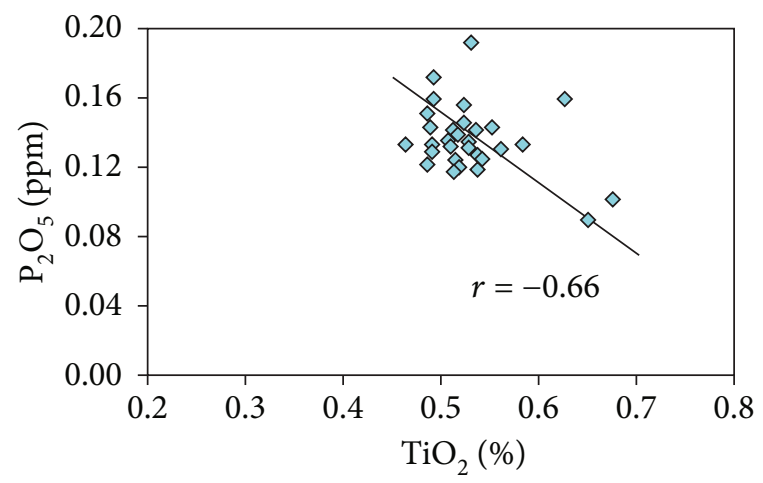

(e)

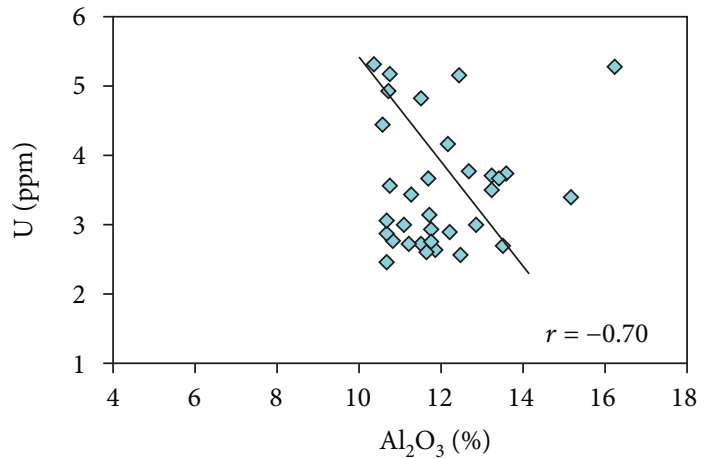

(b)

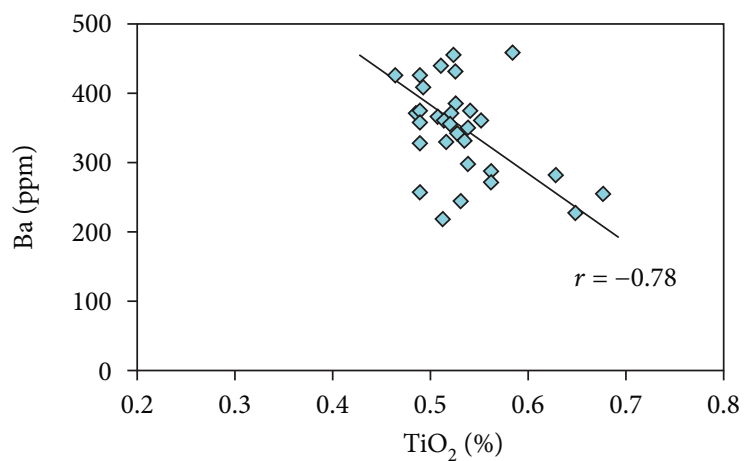

(d)

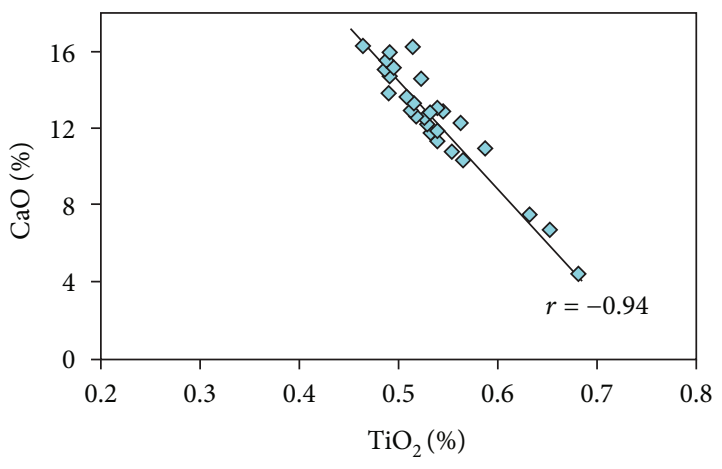

(f)

Figure 6: Correlations between $\mathrm{Al}_{2} \mathrm{O}_{3}$ and $\sum \operatorname{REE}(\mathrm{a}), \mathrm{U}(\mathrm{b})$ and $\mathrm{Th}(\mathrm{c})$, and between $\mathrm{TiO}_{2}$ and $\mathrm{Ba}(\mathrm{d}), \mathrm{P}_{2} \mathrm{O}_{5}(\mathrm{e})$ and $\mathrm{CaO}$ (f) for the $\mathrm{M} 3$ mudstones in Well DW1.

which are lower than that of PAAS $(\mathrm{CIA}=70.4)$ [47]. These low CIA data indicate a low paleoweathering condition. This CIA value can be corrected in the A-CN-K diagram (Figure 8(b)), in which these samples are plotted between 50.0 and 65.0 .

In general, CIA is also used to reconstruct the paleoclimatic conditions $[49,51,66]$. A CIA value $>80 \sim 100$ is indicative of a hot climate, $>70 \sim 80$ indicates a warm and humid climatic setting, and $>50 \sim 70$ corresponds to a relatively cool and arid paleoclimate. Therefore, the low CIA values (53.0 65.0) in the present study indicate a low chemical weathering with cool and arid paleoclimatic condition.

Previous studies have documented that $\mathrm{Fe}, \mathrm{Mn}, \mathrm{V}, \mathrm{Cr}$, $\mathrm{Co}$, and $\mathrm{Ni}$ are relatively enriched under the humid condi- tions, whereas $\mathrm{Ca}, \mathrm{K}, \mathrm{Sr}, \mathrm{Na}, \mathrm{Mg}$, and $\mathrm{Ba}$, being associated with saline mineral precipitates, are comparatively concentrated under arid climatic conditions [67-70]. Taken into consideration of their geochemical behaviors, the C-value was then proposed as an indicator for inferring the paleoclimate $[7,67,71]$. The $\mathrm{C}$-value was defined as follows:

$\mathrm{C}-$ value $=\sum(\mathrm{Fe}+\mathrm{Mn}+\mathrm{Cr}+\mathrm{Ni}+\mathrm{V}+\mathrm{Co}) / \sum(\mathrm{Ca}+\mathrm{Mg}+\mathrm{Sr}+\mathrm{Ba}+\mathrm{K}+\mathrm{Na})$.

The C-value of $0 \sim 0.2,0.2 \sim 0.4,0.4 \sim 0.6,0.6 \sim 0.8$, and $0.8 \sim 1.0$ corresponds to arid, semiarid, semiarid to 


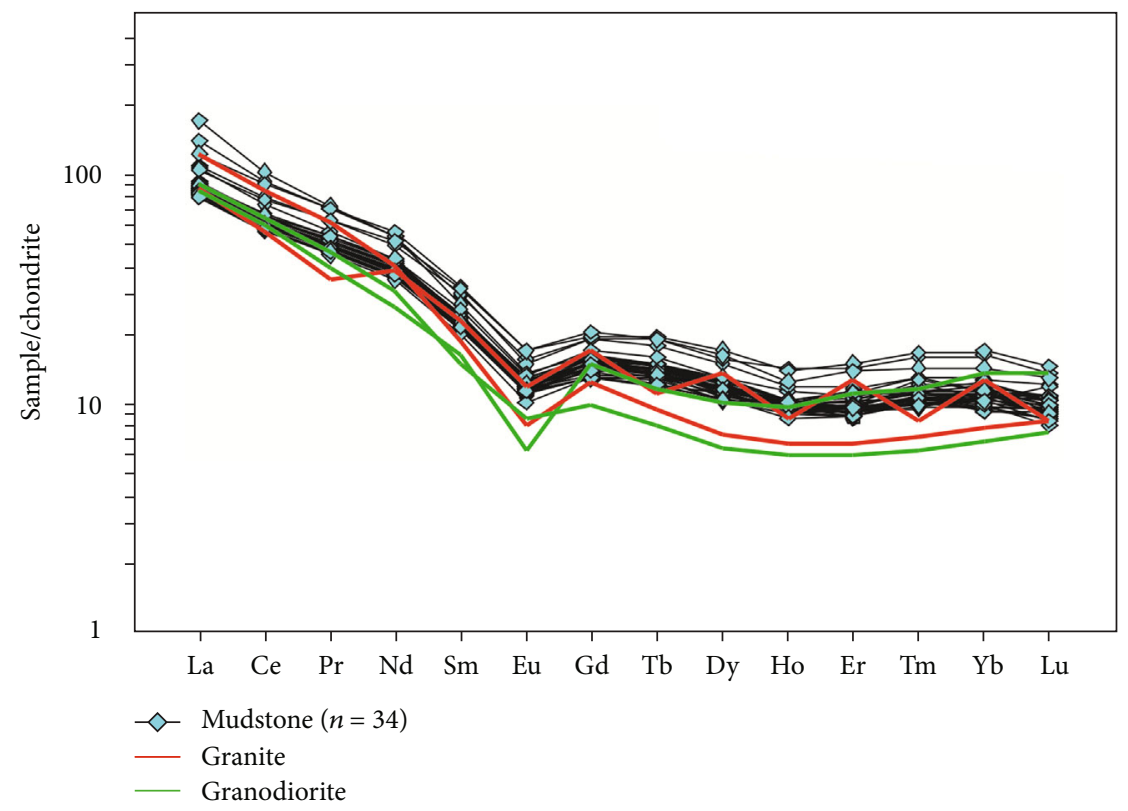

FIGURE 7: Chondrite-normalized [48] REE spider plots of the M3 mudstones in Well DW1. Red and green lines represent the chondritenormalized patterns of Paleozoic granite and granodiorite for comparisons, respectively [35, 38]; (Zhang et al., 2016).

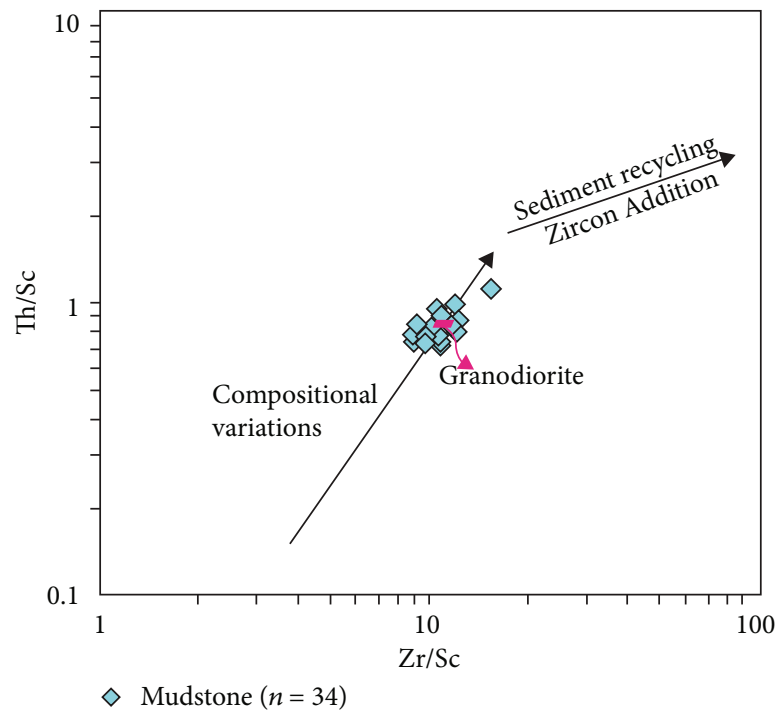

(a)

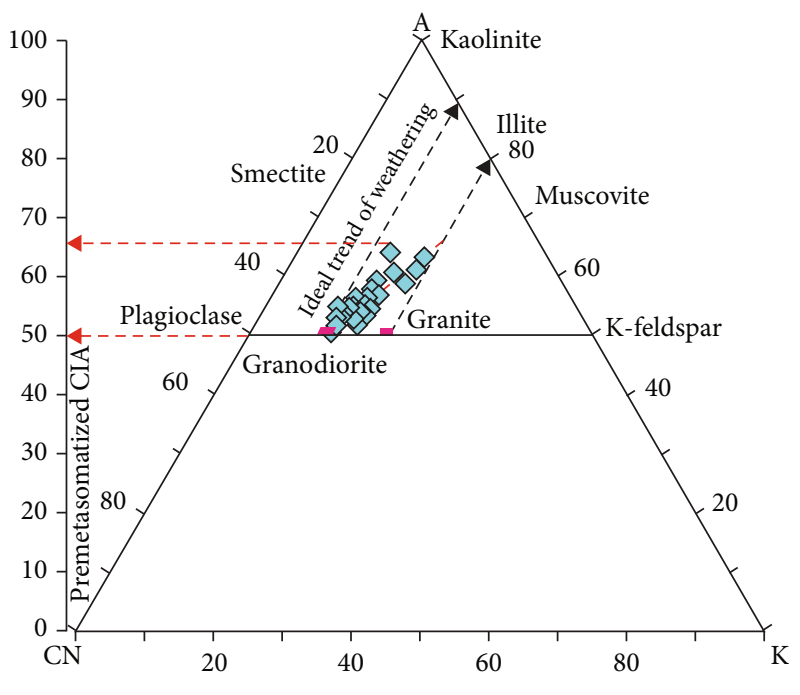

(b)

Figure 8: (a) Cross-plot of $\mathrm{Zr} / \mathrm{Sc}$ versus Th/Sc (after McLennan et al., [49]) showing minimal influence of heavy mineral sorting and recycling. (b) $\mathrm{Al}_{2} \mathrm{O}_{3}-\left(\mathrm{CaO}^{*}+\mathrm{Na}_{2} \mathrm{O}\right)-\mathrm{K}_{2} \mathrm{O}(\mathrm{A}-\mathrm{CN}-\mathrm{K})$ ternary diagram (modified after Nesbitt and Young, 1982, 1984) for $\mathrm{M} 3$ mudstones. $\mathrm{A}=\mathrm{Al}_{2} \mathrm{O}_{3}, \mathrm{CN}=\mathrm{CaO}^{*}+\mathrm{Na}_{2} \mathrm{O}, \mathrm{K}=\mathrm{K}_{2} \mathrm{O}$ (all in molar percentages). Black dashed lines with arrows represent the ideal weathering trends of granodiorite and granite [51]. Red dashed lines with arrows show the premetasomatized CIA values for the samples.

semihumid, semihumid, and humid climatic conditions, respectively [72]. C-values for all the studied samples vary from 0.2 to 0.59 averaging 0.35 (Table 2). As most Cvalues are restricted between 0.2 and 0.4 , this suggests a relatively stable semiarid paleoclimate during the depositions. Other samples with relatively moderate $\mathrm{C}$-values $(>0.4-0.6)$ are indicative of semiarid to semihumid climatic conditions (Figure 11(a)).
Besides, ratios of $\mathrm{Sr} / \mathrm{Cu}$ and $\mathrm{Rb} / \mathrm{Sr}$ can also be employed for characterizing the paleoclimatic changes [67-69]. The $\mathrm{Sr} / \mathrm{Cu}$ ratio will increase, while the $\mathrm{Rb} / \mathrm{Sr}$ ratio decreases under drier and/or hotter climatic conditions. $\mathrm{Sr} / \mathrm{Cu}$ and $\mathrm{Rb} / \mathrm{Sr}$ ratios for all the studied samples range from 5.22 to 34.17 and 0.11 to 1.05 , respectively. The statistically high $\mathrm{Sr} / \mathrm{Cu}(>5.0)$ and low $\mathrm{Rb} / \mathrm{Sr}(<0.4)$ ratios reflect a relatively arid climatic conditions (Figures 11(a) and 11(b)). From 


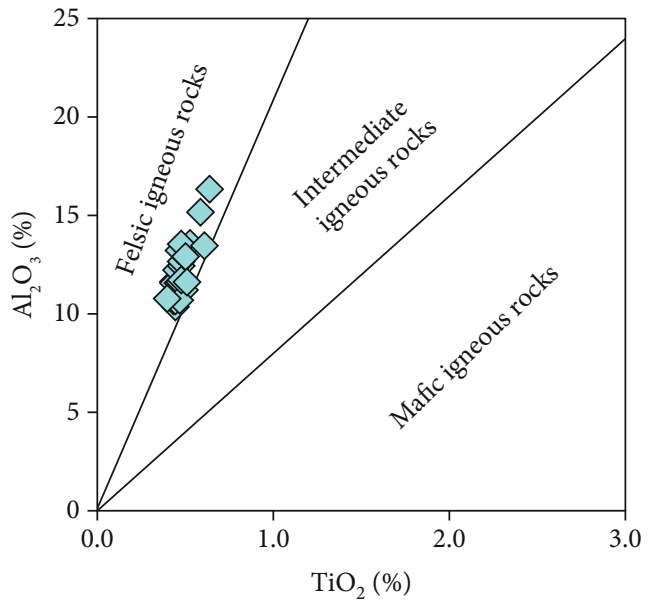

$\diamond$ Mudstone $(n=34)$

(a)

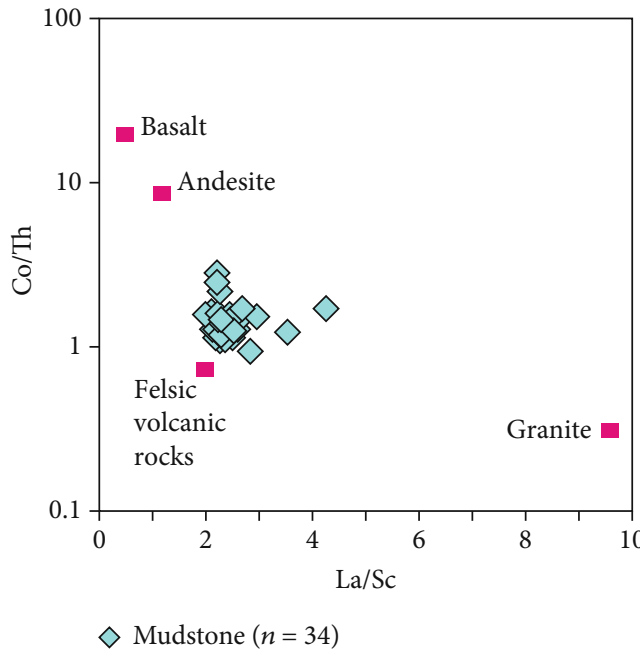

(c)

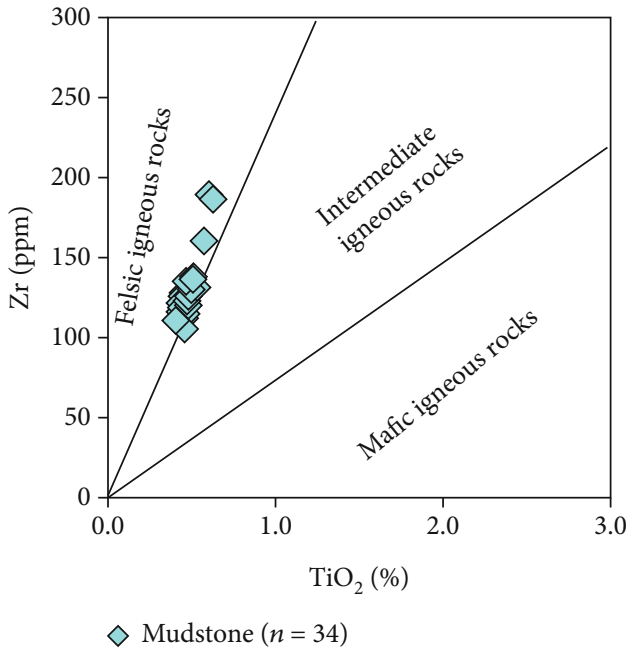

(b)

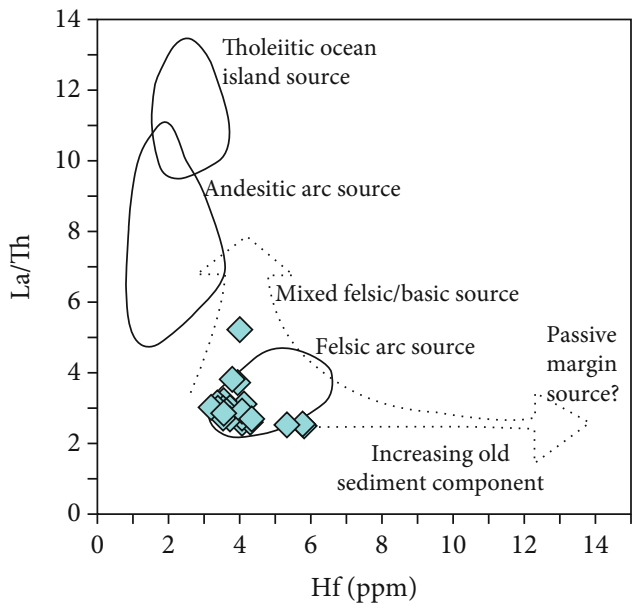

$\diamond$ Mudstone $(n=34)$

(d)

Figure 9: Provenance discrimination cross-plots of the $\mathrm{M} 3$ mudstones. (a) $\mathrm{TiO}_{2}$ versus $\mathrm{Al}_{2} \mathrm{O}_{3}$ [61]. (b) $\mathrm{TiO}_{2}$ against $\mathrm{Zr}$ [61]. (c) $\mathrm{La} / \mathrm{Sc}$ versus Co/Th [62]. (d) Hf against La/Th [63].

the bottom to top in the M3 section, the paleoclimate exhibits a relatively stable semiarid condition (Figure 3 ).

\subsection{Paleoredox, Paleosalinity, and Primary Productivity}

5.4.1. Paleoredox Condition. Redox state is generally divided into four gradients: oxic $\left(>2 \mathrm{ml} \mathrm{O}_{2} \mathrm{~L}^{-1}\right)$, dysoxic $\left(2-0 \mathrm{ml} \mathrm{O}_{2}\right.$ $\left.\mathrm{L}^{-1} \mathrm{ml}_{\mathrm{O} 2} / \mathrm{L}_{\mathrm{H} 2 \mathrm{O}}\right)$, anoxic $\left(0 \mathrm{ml} \mathrm{O}_{2} \mathrm{~L}^{-1}\right)$, and euxinic $(0 \mathrm{ml} \mathrm{O}$ $\left.\mathrm{L}^{-1}, \mathrm{H}_{2} \mathrm{~S}>0\right)$ conditions $[13,20,73]$. Recently, many redox proxies have been established to interpret redox conditions in water columns $[12,18-20]$.

In general, under reducing water columns, $\mathrm{U}(\mathrm{VI})$ is more easily reduced to $U$ (IV), which will accelerate the removal of $\mathrm{U}$ from the water column to sediments (especially when organic materials exist) [20]. In contrast, insoluble Th (IV) is unaffected by the redox changes. In the present study, $\mathrm{U}$ and Th elements display negative $(r=-0.70)$ and positive $(r=0.93)$ correlations with $\mathrm{Al}_{2} \mathrm{O}_{3}$ (Figures 6(b) and 6(c)), and to a certain extent, using $\mathrm{U} / \mathrm{Th}$ ratio to study the redox states are also suitable. Some authors suggest that a U/Th ratio $<0.27,0.27-0.5$, and $>0.5$ corresponds to oxidizing, dysoxic, and anoxic environments, respectively [74-76]. These samples exhibit moderate U/Th values (0.24 0.65; Table 3), but most values are distributed in the range of $0.27 \sim 0.49$ $(n=26)$, implying dominant oxic-dysoxic bottom water conditions (Figure 3).

Another quantitative index for the redox state is the $\mathrm{Cu} / \mathrm{Zn}$ ratio [77-79]. With a decrease in oxygen fugacity, vertical zonation from $\mathrm{Cu}$ enrichment towards $\mathrm{Zn}$ enrichment can develop in water columns during depositions [79]. A $\mathrm{Cu} / \mathrm{Zn}$ ratio $<0.21,0.21-0.38,0.38-0.5,0.5-0.63$, and $>0.63$ represents anoxic, weak anoxic, weak anoxic to weak oxidizing (viz., anoxic to oxidizing transition), weak oxidizing, and oxidizing conditions, respectively [79]. $\mathrm{Cu} / \mathrm{Zn}$ values for all the studied samples range from 0.17 to 0.75 (Table 3 ) and reflect an undulatory anoxic-oxic water condition. However, most of the $\mathrm{Cu} / \mathrm{Zn}$ values vary between 0.21 and $0.50(n=25$ ), suggesting weak anoxic-weak oxidizing (dysoxic) water 


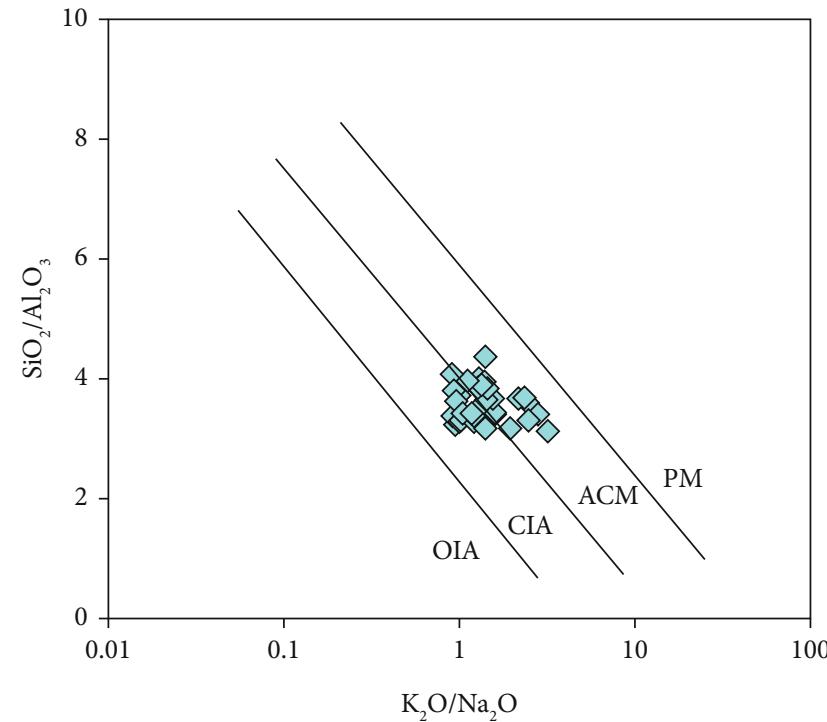

Mudstone $(n=34)$

(a)

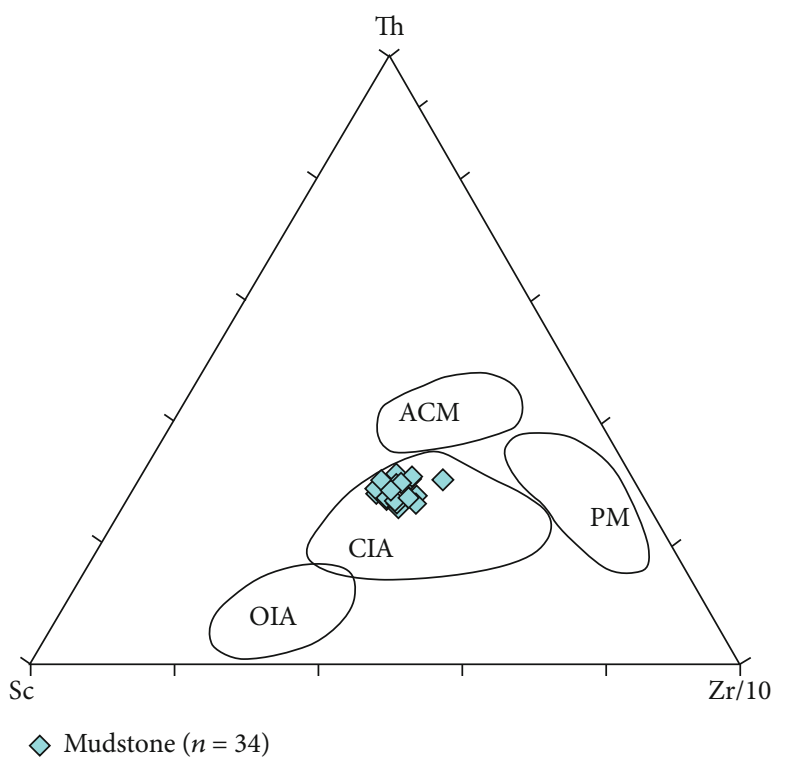

(c)

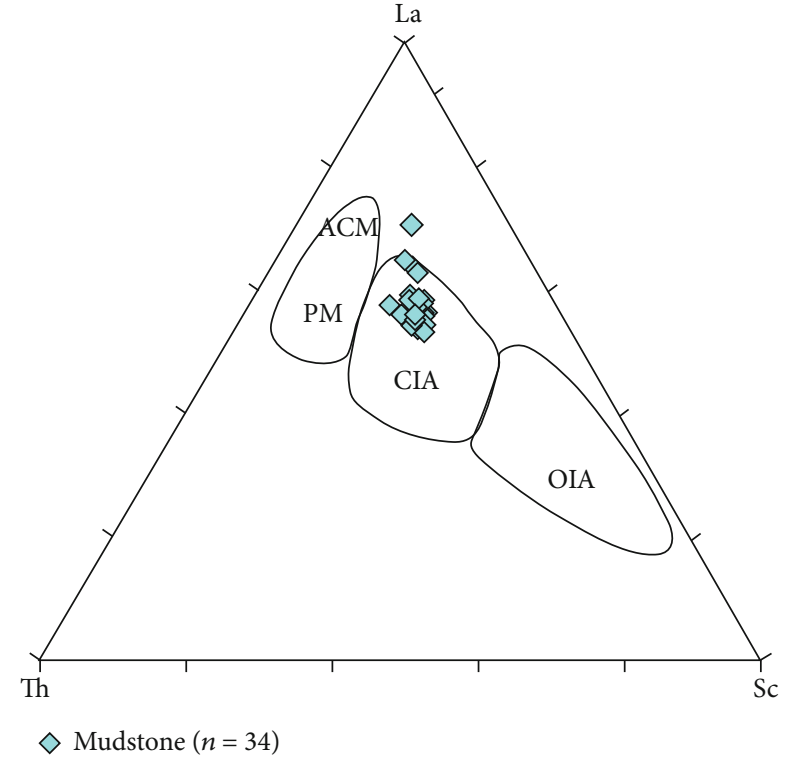

(b)

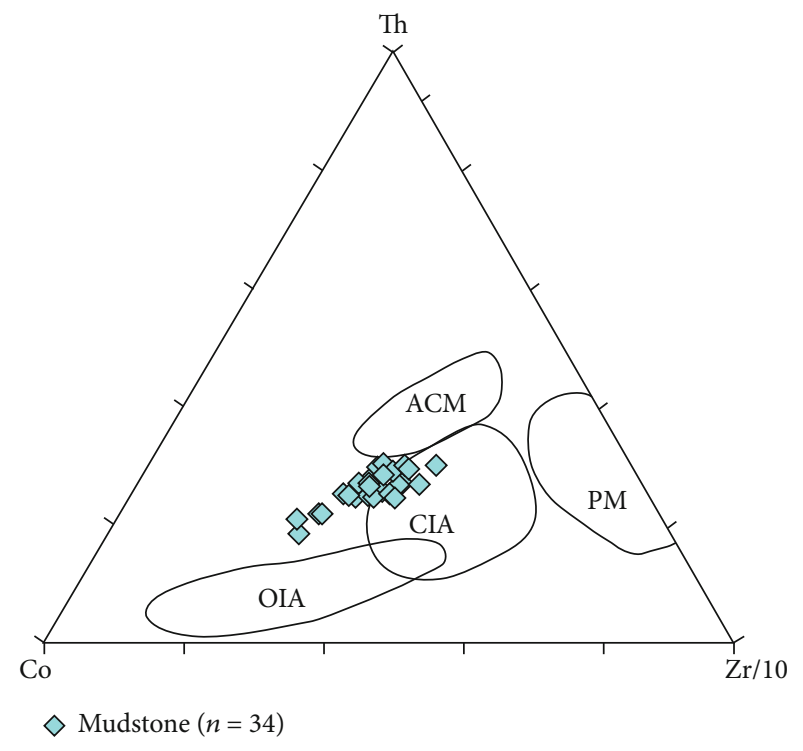

(d)

Figure 10: Tectonic setting discrimination diagrams for the $\mathrm{M} 3$ mudstones. (a) $\mathrm{SiO}_{2} / \mathrm{Al}_{2} \mathrm{O}_{3}$ versus $\mathrm{K}_{2} \mathrm{O} / \mathrm{Na}_{2} \mathrm{O}$ (after Roser and Korsch, [65]). (b), (c), and (d) La-Th-Sc, Th-Sc-Zr/10, and Th-Co-Zr/10 [57], respectively. Abbreviations: OIA: oceanic island arc; CIA: continental island arc; ACM: active continental margin; PM: passive margin.

columns. Other samples $(n=9)$ show $\mathrm{Cu} / \mathrm{Zn}$ values lower than 0.21 or higher than 0.5 , which are indicative of some episodes of anoxic or oxidizing water environments, respectively.

Algeo and Tribovillard [19] investigated the covariations in $U$ and Mo enrichment factors in some modern lowoxygen marine basins and established three Mo-U covariation patterns associated with different specific redox conditions and enrichment processes like "unrestricted marine," "particulate shuttle," and "strongly restricted basin" [19, 80]. These $\mathrm{Mo}_{\mathrm{EF}}-\mathrm{U}_{\mathrm{EF}}$ covariation patterns have successfully been applied to reconstruct the redox environments in both ancient oceans and lakes $[80,81]$. The $\mathrm{U}_{\mathrm{EF}}$ values for all the studied samples are greater than 1.0, varying between 1.21 and 3.15 with an average of 1.88 , revealing a relatively stable enrichment of $\mathrm{U}$ in these mudstones. In contrast, $\mathrm{Mo}_{\mathrm{EF}}$ displays a wide range of $0.27-5.0$ averaging 1.19 , suggesting variable degrees of depletion or enrichment. Relatively low MoEF leads to the $(\mathrm{Mo} / \mathrm{U})_{\text {sample }}$ ratio to be $0.1 \sim 0.3$ times of seawater for most studied samples. When plotted into a cross-plot of $\mathrm{U}_{\mathrm{EF}}$ versus $\mathrm{Mo}_{\mathrm{EF}}, \mathrm{U}_{\mathrm{EF}}$ exhibits a positive correlation with $\mathrm{Mo}_{\mathrm{EF}}$ (Figure 12), suggesting relatively less fluctuation of redox conditions during the depositions. Additionally, Mo and $\mathrm{U}$ accumulation may not be influenced 


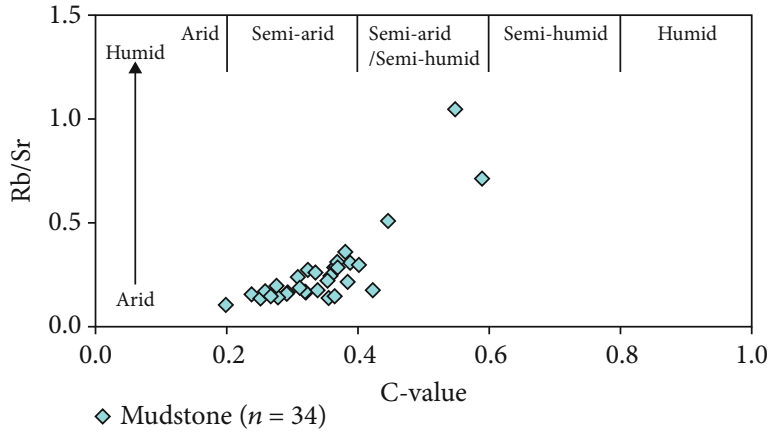

(a)

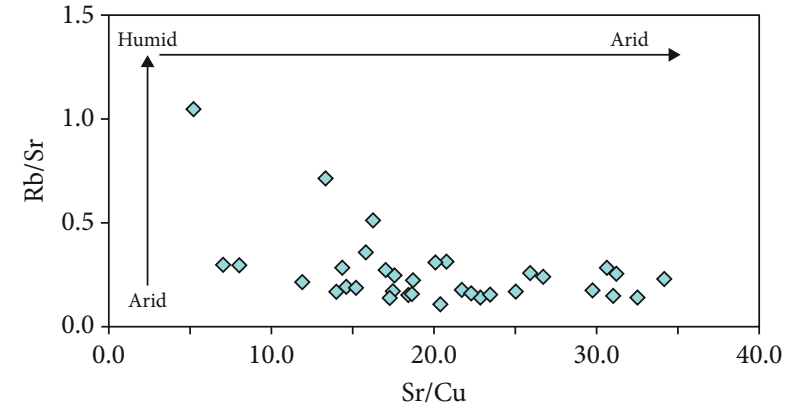

(b)

Figure 11: Cross-plots of $\mathrm{Rb} / \mathrm{Sr}$ versus $\mathrm{C}$-value (a) and $\mathrm{Rb} / \mathrm{Sr}$ versus $\mathrm{Sr} / \mathrm{Cu}$ (b) for the M3 mudstones, showing a dominant semiarid paleoclimate.

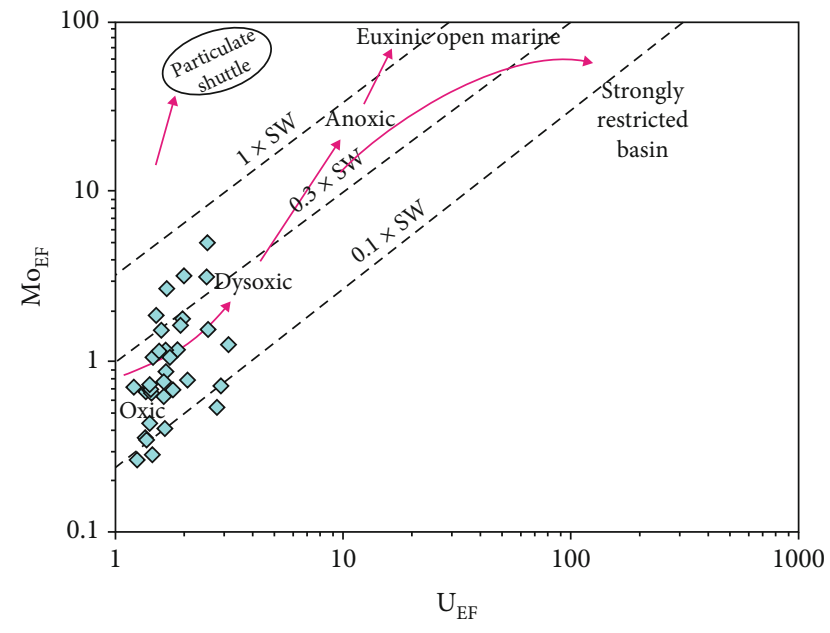

$\diamond$ Mudstone $(n=34)$

FIGURE 12: $\mathrm{U}_{\mathrm{EF}}$ versus $\mathrm{Mo}_{\mathrm{EF}}$ covariation pattern for the mudstones (modified after Algeo and Tribovillard, [18]; Tribovillard et al., [80]), showing oxic-dysoxic water conditions. Diagonal dashed lines refer to $\mathrm{Mo} / \mathrm{U}$ molar ratios of the Seawater (SW).

by an active particulate shuttle, but are largely controlled by oxic to dysoxic conditions (Figure 12). In dysoxic waters close to the Fe (III)-Fe (II) transition, soluble U (VI) can be largely reduced to insoluble $U$ (IV) and, then, preferentially incorporated into the sediments over Mo element (especially in the presence of OM) $[29,81]$. This is consistent with that the level of $U$ enrichment is greater than that of Mo enrichment in most samples. However, the Mo accumulation in these mudstones may not be due to the coprecipitation or absorption onto the Mn-Fe oxyhydroxides but may have been captured by sulfurized $\mathrm{OM}$ or Fe-S phase with different enrichment degrees under dysoxic conditions and subsequently converted into particle-reactive thiomolybdate ions $\left(\mathrm{MoO}_{\mathrm{x}}{ }^{2-} \mathrm{S}_{4-\mathrm{x}}, \mathrm{x}=0-3\right)$ [20]. This inference is further indicated by the obvious positive relationships between $\mathrm{Mo}_{\mathrm{EF}}$ and TOC and S (Figure 3).

5.4.2. Paleosalinity. Salinity is a fundamental feature of watermasses that is useful for paleoenvironment reconstruction in ancient oceans and lakes. Paleosalinity in this study was esti- mated using $\mathrm{Sr} / \mathrm{Ba}, \mathrm{B}, \mathrm{TOC} / \mathrm{S}$, and biomarker parameters. The $\mathrm{Sr} / \mathrm{Ba}$ ratio typically increases along with enhanced water salinity $[46,82-86]$. Sr/Ba values of all the samples range from 0.56 to 2.36 , and only five samples have relatively low $\mathrm{Sr} / \mathrm{Ba}$ values that are lower than 1.0 (Table 3 ), suggesting typical marine or high-saline environments but interspersed with several episodes of brackish water. According to the reassessment of Wei and Algeo [46], the TOC/S ratio is much more accurate than the $\mathrm{Sr} / \mathrm{Ba}$ ratio in predicting paleosalinity, and ratios of $>10,2-10$, and $<2$ are broadly suggestive of freshwater, brackish, or marine, and marine facies, respectively. About $27 \%$ of the studied samples have TOC/S values lower than 2.0, while other samples show moderate TOC/S values of 2.39 9.97. These data possibly suggest a dominant brackish water column but with some episodes of a marine (or high saline) environment. The above inference is slightly different from the high-saline-dominated paleosalinity derived from $\mathrm{Sr} / \mathrm{Ba}$ ratios; however, it corresponds to the results from the B proxy as discussed below.

The $\mathrm{B}$ concentration and relevant indicators can provide a quantitative assessment of paleosalinity [82-84]. The proxy of equivalent $B\left(B_{e q}\right)$ is usually calculated using the method of Walker and Price [85], and values of $<200 \times 10^{-6}, 200 \times$ $10^{-6} \sim 300 \times 10^{-6}$, and $>300 \times 10^{-6}$ are indicative of freshwater, brackish water, and marine or high-saline facies. Furthermore, Adams et al. [82] proposed another indicator of Svalue to estimate the paleosalinity of ancient water-masses, as

$$
S-\text { value }=0.0977 \times B_{\text {eq }}-7.043,
$$

where the S-value represents the paleosalinity (\%o). In general, the calculated S-value $<10 \%$ indicates a freshwater environment, $>10-25 \%$ is suggestive of a brackish condition, and $>25-35 \%$ reflects a high-saline water (or marine) water. The studied samples have relatively high $\mathrm{B}_{\mathrm{eq}}$ and S-values, ranging from $232.1 \times 10^{-6}$ to $380.5 \times 10^{-6}$ and from $15.6 \%$ to $30.1 \%$, respectively (Table 3 ). These data reflect a relatively stable, stratified brackish water column with some episodes of high-saline condition during the lacustrine mudstone deposition (Figure 3). Additionally, B/Ga ratio can also be a common index to evaluate the paleosalinity, and $\mathrm{B} / \mathrm{Ga}$ ratio for $<3.0,3.0 \sim 6.0$, and $>6.0$ is indicative of 


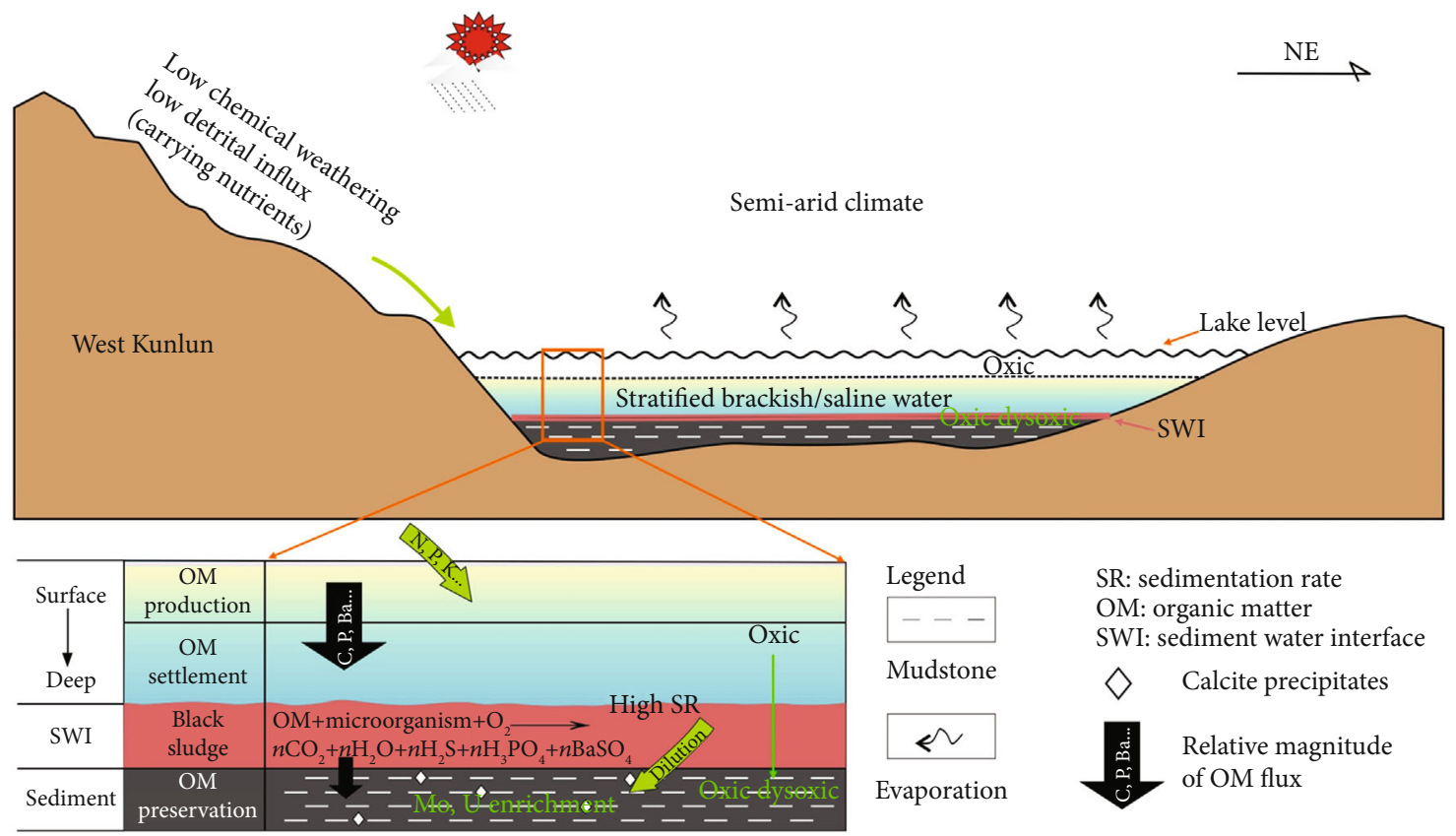

FIGURE 13: The Sketch map of the sedimentary environments and developing model of the OM enrichment for the M3 mudstones in the Yecheng-Hetian Sag.

freshwater, brackish, and marine facies, respectively [46]. These samples have higher $\mathrm{B} / \mathrm{Ga}$ ratios, ranging from 7.85 to 12.09 (average 9.6), pointing out the typical marine facies. Considering the fact that this period was the regressive lacustrine deposition, we thus interpret that the higher $\mathrm{B} / \mathrm{Ga}$ ratios represent the high-saline water body, consistent with the above inferences.

Moreover, some biomarker parameters, such as pristine/phytane $(\mathrm{Pr} / \mathrm{Ph})$ and gammacerane $/ \mathrm{C}_{30}$ hopane $\left(\mathrm{G} / \mathrm{C}_{30}\right)$, are also effectively applied to infer the paleosalinity [87]. Relatively high $\mathrm{G} / \mathrm{C}_{30}\left(\mathrm{G} / \mathrm{C}_{30}=0.18-0.3\right)$ and low $\mathrm{Pr} / \mathrm{Ph}$ ratios $(\mathrm{Pr} / \mathrm{Ph}=0.06-0.62)$, along with their negative correlations reported in our previous study [25], also suggest relatively high-saline water conditions.

Overall, the relatively high-saline paleosalinity might result from the strong evaporation induced by drier and/or hotter climate in a relatively closed lake during the M3 deposition period [88], as indicated by the positive or negative correlations between $\mathrm{C}$-value, $\mathrm{Sr} / \mathrm{Cu}, \mathrm{Sr} / \mathrm{Ba}, \mathrm{B}_{\text {eq }}$, and S-value (Figure 3).

5.4.3. Primary Productivity. The primary productivity is a crucial indicator to reveal the degree of OM enrichment. Several geochemical proxies, such as TOC, organic phosphorus $\left(\mathrm{P}_{\text {org }}\right)$, and biogenic barium $\left(\mathrm{Ba}_{\text {bio }}\right)$, are often useful for evaluating the paleoproductivity during the formation of organic-rich sediments (as discussed by Schoepfer et al. [9]). Although the TOC content provides the most direct implication for paleoproductivity, the application of this index is limited in the present study due to relatively high thermal maturation (which can largely accelerate the loss of organic carbon). Phosphorus is regarded as a fundamental nutrient element for all organisms and can originate from detrital and organic phosphorus sources [9]. However, in organic-rich sediments, detrital $\mathrm{P}$ can be neglected because of its low proportion $(<20 \%)$ in total P, based on statistical analysis $[9,75]$. Therefore, the $\mathrm{P}_{\text {org }}$ content is approximately equivalent to the measured P. Similarly, biogenic barium $\left(\mathrm{Ba}_{\text {bio }}\right)$ is also associated with the sinking flux of $\mathrm{OM}$ and is another important proxy of primary productivity $[9,20]$. The $\mathrm{Ba}$ and $\mathrm{P}$ contents exhibit relatively negative correlations with $\mathrm{TiO}_{2}(r=-0.78$ and -0.66 , respectively) (Figures 6(d) and $6(\mathrm{e}))$, to a large extent, reflecting the organic origins. The Ti- and Al-normalized indicators (e.g., $\mathrm{P} / \mathrm{Ti}$ and $\mathrm{Ba} / \mathrm{Al}$ ) can be used to eliminate the impact of terrigenous fractions [75], and thereafter, the primary productivity can be effectively evaluated using these indicators. The $\mathrm{P} / \mathrm{Ti}$ and $\mathrm{Ba} / \mathrm{Al}$ ratios of the samples show relatively narrow ranges of 0.14 0.36 ( 0.26 on average) and 15.69-41.32 (29.24 on average) (Table 2). In terms of the P/Ti ratio, this ratio for the studied samples is higher than that of PAAS $(\mathrm{P} / \mathrm{Ti}=0.13)$ [47], and Permian Lucaogou Formation fine-grained rocks $(\mathrm{P} / \mathrm{Ti}=0.16$ on average) with high TOC contents $(\sim 4.22 \%$ on average) in the Santanghu Basin [88], implying a relatively high primary productivity with stable vertical variations during the M3 deposition period.

5.5. Enrichment Mechanism and Developing Model of Organic Matter. The accumulation, preservation, and enrichment of OM are usually affected by several fundamental factors, such as paleoclimate, primary productivity, detrital influx, redox states, sedimentation rate, and sea/lake-level [1-7]. However, each sedimentary environment may have its specific elements; and therefore, the enrichment mechanism of OM cannot be explained by a single controlling factor. In this study, the covariations between various controlling factors and TOC and P/Ti will be used to evaluate the controlling factors on the enrichment process of OM. 


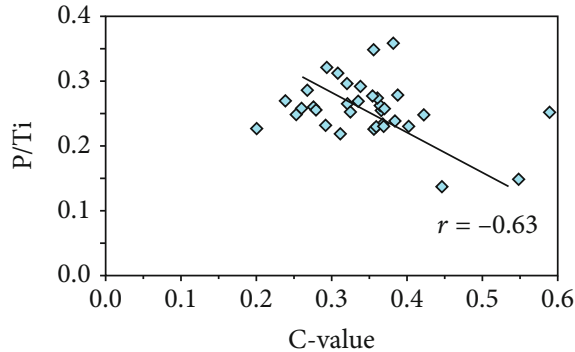

$\diamond$ Mudstone $(n=34)$

(a)

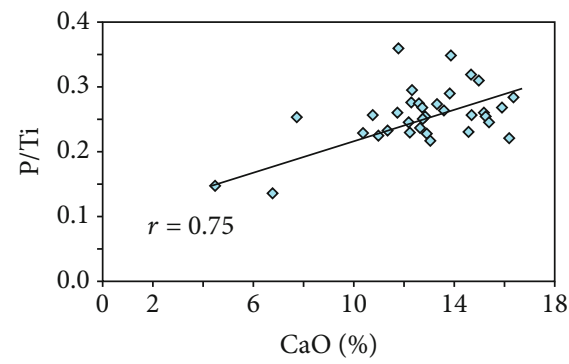

(c)

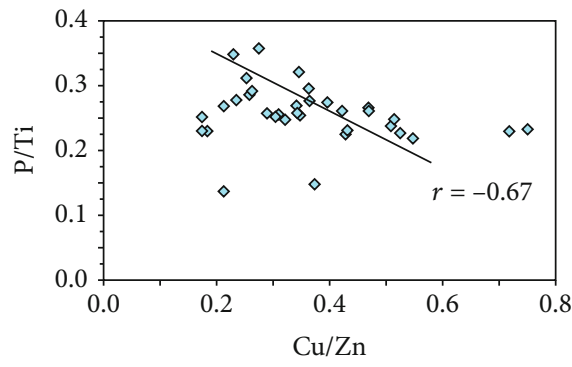

(e)

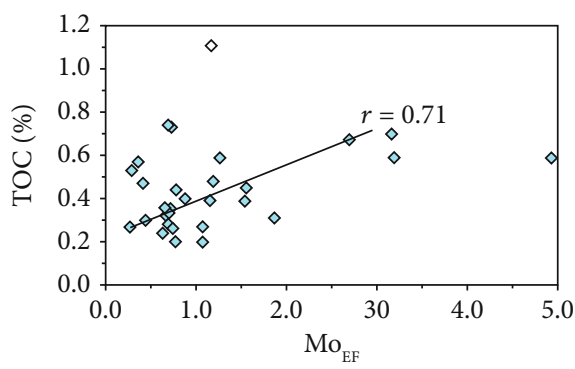

(g)

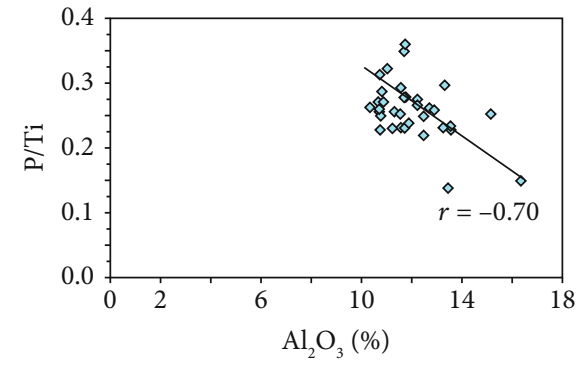

(b)

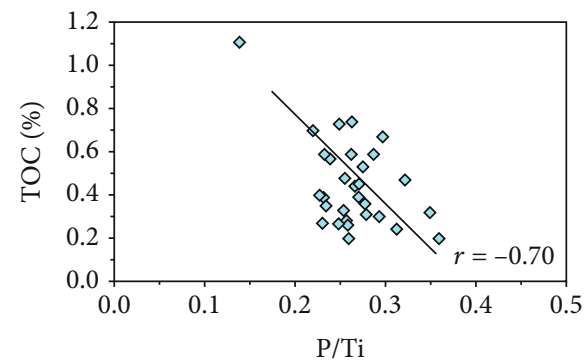

(d)

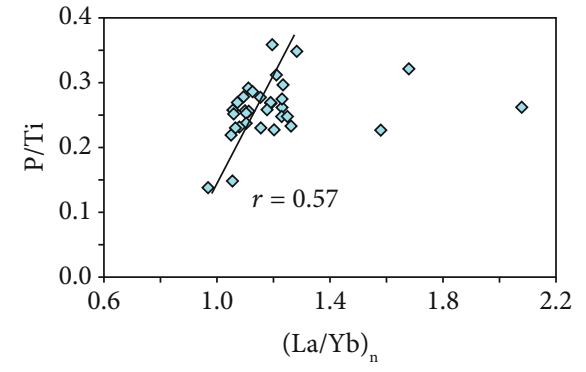

(f)

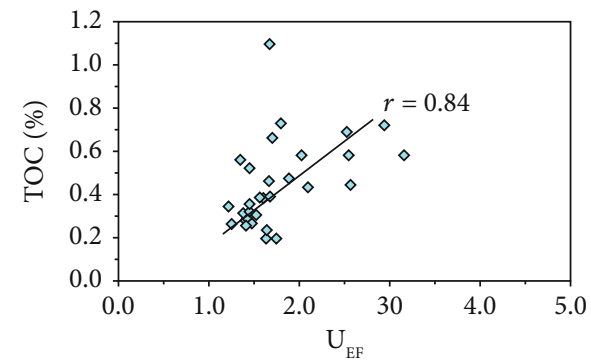

(h)

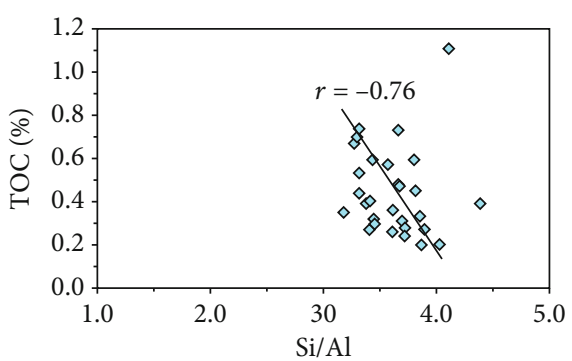

(i)

Figure 14: Relationships between different indexes for the M3 mudstones, reflecting controlling factors for the OM enrichment. (a) C-value versus P/Ti. (b) $\mathrm{Al}_{2} \mathrm{O}_{3}$ versus $\mathrm{P} / \mathrm{Ti}$. (c) $\mathrm{CaO}$ versus $\mathrm{P} / \mathrm{Ti}$. (d) TOC versus $\mathrm{P} / \mathrm{Ti}$. (e) $\mathrm{Cu} / \mathrm{Zn}$ versus $\mathrm{P} / \mathrm{Ti}$. (f) $\left(\mathrm{La} / \mathrm{Yb}\right.$ ) ${ }_{\mathrm{n}}$ versus $\mathrm{P} / \mathrm{Ti}$. (g) $\mathrm{Mo} \mathrm{EF}_{\mathrm{EF}}$ versus TOC. (h) $\mathrm{Mo}_{\mathrm{EF}}$ versus TOC. (i) Si/Al versus TOC. " $r$ " represents correlation coefficient. 
The northward subduction of Kangxiwar Paleo-Tethys downwards the Tarim Plate at the beginning of the late Early Permian ended the marine sedimentation and developed such thick (>2000 m) continental clastic depositions in the Hetian region. Along with the gradual release of tectonic stress, the Permian sedimentary basin entered a relatively stable period of tectonic setting, provenance supply, and depositional environments during the M3 deposition period (Figure 13). This is supported that most geochemical parameters exhibit weak fluctuations upward from the bottom to top in the Well DW1 (Figure 3). Under such stable sedimentary backgrounds, the semiarid and low weathering dominated conditions resulted in low detrital influx input with carrying a certain amount of soluble nutrients, promoting the relatively high primary OM generation, as supported by the negative relationships between $\mathrm{P} / \mathrm{Ti}$ and $\mathrm{C}$-value, and $\mathrm{Al}_{2} \mathrm{O}_{3}(r=-0.63$ and -0.70 , respectively; Figures $14(\mathrm{a})$ and 14(b)). The $\mathrm{CaO}$ contents are negatively or positively correlated with $\mathrm{Ti}$ and $\mathrm{P} / \mathrm{Ti}(r=-0.94$ and 0.75 , respectively; Figures 6(f) and $14(\mathrm{c})$ ). This illustrates that $\mathrm{CaO}$ possibly derived from the authigenic carbonate precipitation due to the low annual precipitation and strong evaporation, which were closely associated with the formation process of $\mathrm{OM}$ in M3 lacustrine mudstones.

Unlike typical positive correlations between the primary productivity index (e.g., $\mathrm{P} / \mathrm{Ti}$ ) and TOC contents in most studies $[17,75]$, TOC contents in the present study display a negative relationship with the $\mathrm{P} / \mathrm{Ti}$ ratio $(r=-0.70$; Figure $14(\mathrm{~d})$ ). This result may suggest that the preservation conditions instead of primary productivity are much more important for the enrichment of $\mathrm{OM}$ and, also, reflect that the primary OM inevitably experienced some degree of postdepositional oxidation. Fe/Mn ratio can be generally used as a common index for the relative paleowater depth [88, 89]. As shown in Figure 3, under relatively deep-waters (low $\mathrm{Fe} / \mathrm{Mn}$ ratio), the TOC contents, primary productivity, and paleosalinity are relatively higher, and the redox state is relatively more reducing (but not up to dysoxic level) relative to the relatively shallow-waters (high Fe/Mn ratio). Therefore, we assumed that when primary OM reached below the sediment-water interface (SWI), most of them were progressively decomposed through the consumption of oxygen and then released $\mathrm{CO}_{2}$ into the water columns (Figure 13). As a result, oxic-dysoxic water columns, instead of that prevailed prior to sediment depositions [20], were gradually developed above and below the SWI. Meanwhile, related authigenic carbonates were then precipitated below the SWI as mentioned above. The primary productivity index (e.g., $\mathrm{P} / \mathrm{Ti}$ ratio) is negatively related with $\mathrm{Cu} / \mathrm{Zn}$ ratio, and TOC contents $(r=-0.67$ and -0.7 , respectively; Figures $14(\mathrm{~d})$ and $14(\mathrm{e}))$ can support the above-mentioned conclusion: the relatively high primary productivity corresponds to the relatively more reducing conditions and relatively lower TOC contents. In this circumstance, this process may not only have preserved some amounts of organic carbon below the SWI but also accelerated the removal of $U$ and Mo towards into the sediments with various enrichment degrees (indicated by the strong positive covariations between TOC and $\mathrm{Mo}_{\mathrm{EF}}$ and $\mathrm{U}_{\mathrm{EF}}(r=0.71$ and 0.84 , respectively; Figures $14(\mathrm{~h})$ and $14(\mathrm{i}))$.
Sedimentation rate (SR) and detrital influx may also play potential effects on $\mathrm{OM}$ enrichment. $\mathrm{Ti}, \mathrm{Si}$, and $\mathrm{Zr}$ are mainly derived from aluminosilicate and heavy minerals, and Alnormalized ratios are effective indicators for evaluating the degree of detrital influx [6]. A good negative relationship between the TOC and detrital indicator of $\mathrm{Si} / \mathrm{Al}$ ratio ( $r=-0.76$; Figure 14(i)) suggests the obvious dilution effect of detrital materials in TOC abundance. The $(\mathrm{La} / \mathrm{Yb})_{\mathrm{n}}$ (where " $n$ " represents the North American Shale Composition, NASC [90]) is regarded as a potential proxy to reflect the $S R$, and $(\mathrm{La} / \mathrm{Yb})_{\mathrm{n}} \geq 1.0$ represents a rapid SR $[75,90]$. The $(\mathrm{La} / \mathrm{Yb})_{\mathrm{n}}$ values vary from 0.97 to 2.08 (average 1.2; Table 4), revealing a high SR during the M3 deposition period. The positive correlation between $(\mathrm{La} / \mathrm{Yb})_{\mathrm{n}}$ and $\mathrm{P} / \mathrm{Ti}(r=0.57$; Figure $14(\mathrm{f}))$ reflect that high SR contributes to the preservation of primary OM materials, rather than dilution. However, the high SR exerted a weak effect on TOC abundance because no relationship between them was observed in the present study. That can be interpreted that high SR further shortened the exposure time of OM with oxygen $[9,10]$ and, thus, largely decreased the decomposition of OM under oxic-dysoxic water conditions (Figure 13). Likewise, the relatively high-saline, stratified water columns may also exert a certain effect on the preservation of primary OM by restraining the degradation of OM [75], as the paleoclimate and paleosalinity are closely related with each other (Figure 3).

In summary, the enrichment mechanism of OM of the M3 lacustrine mudstones can be regarded as the combination of "preservation model" and "detrital dilution model." Favorable stratified, high-saline, and oxic-dysoxic water conditions, together with high SR, were conducive to the preservation of $\mathrm{OM}$, and the relatively high detrital influx diluted the TOC abundance.

\section{Conclusions}

(1) The M3 lacustrine mudstones are characterized by the relatively low TOC, $S_{1}, S_{2}$, and $\mathrm{HI}$ values and are estimated to be poor- to fair-quality hydrocarbon source rocks with mature type II-III kerogen

(2) Geochemical results showed that M3 mudstones had a relatively stable felsic dominated provenance formed in continental island arc and ACM tectonic settings from the West Kunlun Orogen to the southwest of the Yecheng-Hetian Sag. The depositional environment was the stratified, high-saline water body with oxic-dysoxic conditions, and paleoclimate was inferred as the predominant semiarid climate with some episodes of semihumid condition

(3) Paleoproductvity was not the main controlling factor, and the OM enrichment in these M3 mudstones should be attributed to the preservation conditions and detrital dilution. High sedimentation rate, together with the high-saline, stratified, oxic-dysoxic lake water largely preserved the OM, while detrital dilution exerted a direct effect on TOC abundances in this study 


\section{Data Availability}

The data can be found in the manuscript.

\section{Conflicts of Interest}

The authors declare that they have no conflicts of interest.

\section{Acknowledgments}

Thanks are due to Dr. Youxing Yang and Prof. Zhihong Kang for their help and providing data. This study was financially supported by the National Key Research and Development Program of China (Grant No. 2019YFA0708504), National Natural Science Foundation of China (U19B6003), and the Frontier Project of the Chinese Academy of Sciences (XDA14010201).

\section{References}

[1] M. A. Arthur and B. B. Sageman, "Marine black shales: depositional mechanisms and environments of ancient deposits," Annual Review of Earth and Planetary Sciences, vol. 22, no. 1, pp. 499-551, 1994.

[2] G. J. Demaison and G. T. Moore, "Anoxic environments and oil source bed genesis," AAPG Bulletin, vol. 64, pp. 11791209, 1980.

[3] T. Dong, N. B. Harris, and K. Ayranci, "Relative sea-level cycles and organic matter accumulation in shales of the Middle and Upper Devonian Horn River Group, northeastern British Columbia, Canada: insights into sediment flux, redox conditions, and bioproductivity," Geological Society of America Bulletin, vol. 130, pp. 859-880, 2017.

[4] G. G. Lash and D. R. Blood, "Organic matter accumulation, redox, and diagenetic history of the Marcellus Formation, southwestern Pennsylvania, Appalachian basin," Appalachian Basin Marine \& Petroleum Geology, vol. 57, pp. 244-263, 2014.

[5] H. Mort, O. Jacquat, T. Adatte et al., "The Cenomanian/Turonian anoxic event at the Bonarelli Level in Italy and Spain: enhanced productivity and/or better preservation?," Cretaceous Research, vol. 28, no. 4, pp. 597-612, 2007.

[6] A. E. Murphy, B. B. Sageman, D. J. Hollander, T. W. Lyons, and C. E. Brett, "Black shale deposition and faunal overturn in the Devonian Appalachian Basin: clastic starvation, seasonal water-column mixing, and efficient biolimiting nutrient recycling," Paleoceanography, vol. 15, no. 3, pp. 280-291, 2000.

[7] T. F. Pedersen and S. E. Calvert, "Anoxia vs. productivity: what controls the formation of organic-carbon-rich sediments and sedimentary rocks?," AAPG Bulletin, vol. 74, pp. 454-466, 1990.

[8] J. H. He, W. Ding, Z. Jiang, K. Jiu, A. Li, and Y. Sun, "Mineralogical and chemical distribution of the Es3L oil shale in the Jiyang Depression, Bohai Bay Basin (E China): implications for paleoenvironmental reconstruction and organic matter accumulation," Marine \& Petroleum Geology, vol. 81, pp. 196-219, 2017.

[9] S. D. Schoepfer, J. Shen, H. Y. Wei, R. V. Tyson, E. Ingall, and T. J. Algeo, "Total organic carbon, organic phosphorus, and biogenic barium fluxes as proxies for paleomarine productivity," Earth-Science Reviews, vol. 149, pp. 23-52, 2015.

[10] R. V. Tyson, "Sedimentation rate, dilution, preservation, and total organic carbon: some results of a modelling study," Organic Geochemistry, vol. 32, no. 2, pp. 333-339, 2001.
[11] R. V. Tyson, "The "productivity versus preservation"controversy: cause, flaws, and resolution," in The Deposition of Organic-Carbon-Rich Sediments: Models, Mechanisms, and Consequences, N. B. Harris, Ed., vol. 82, pp. 17-33, Society for Sedimentary Geology (SEPM) Special Publication, 2005.

[12] S. M. Rimmer, J. A. Thompson, S. A. Goodnight, and T. Robl, "Multiple controls on the preservation of organic matter in Devonian-Mississippian marine black shales: geochemical and petrographic evidence," Palaeogeography Palaeoclimatology Palaeoecology, vol. 215, no. 1-2, pp. 125-154, 2004.

[13] R. V. Tyson and T. H. Pearson, "Modern and ancient continental shelf anoxia: an overview," Geological Society, London, Special Publications, vol. 58, no. 1, pp. 1-24, 1991.

[14] J. B. Curtis, "Fractured shale-gas systems," AAPG Bulletin, vol. 86, pp. 1921-1938, 2002.

[15] B. J. Katz and F. Lin, "Lacustrine basin unconventional resource plays: key differences," Marine and Petroleum Geology, vol. 56, pp. 255-265, 2014.

[16] Z. Tan, S. Lu, W. Li et al., "Climate-driven variations in the depositional environment and organic matter accumulation of lacustrine mudstones: evidence from organic and inorganic geochemistry in the Biyang depression, Nanxiang Basin, China," Energy \& Fuels, vol. 33, no. 8, pp. 6946-6960, 2019.

[17] H. Liang, G. Xu, F. Xu, Q. Yu, J. Liang, and D. Wang, "Paleoenvironmental evolution and organic matter accumulation in an oxygen-enriched lacustrine basin: a case study from the Laizhou Bay Sag, southern Bohai Sea (China)," International Journal of Coal Geology, vol. 217, article 103318, 2020.

[18] T. J. Algeo and N. Tribovillard, "Environmental analysis of paleoceanographic systems based on molybdenum-uranium covariation," Chemical Geology, vol. 268, no. 3-4, pp. 211$225,2009$.

[19] J. L. Morford, W. R. Martin, and C. M. Carney, "Uranium diagenesis in sediments underlying bottom waters with high oxygen content," Geochimica et Cosmochimica Acta, vol. 73, no. 10, pp. 2920-2937, 2009.

[20] N. Tribovillard, T. J. Algeo, T. Lyons, and A. Riboulleau, "Trace metals as paleoredox and paleoproductivity proxies: an update," Chemical Geology, vol. 232, no. 1-2, pp. 12-32, 2006.

[21] D. J. Hou, D. J. Xiao, Y. J. Tang, J. Z. Zhu, and X. Q. Li, “Geochemical characterization of mixing natural gas in Kekeya field, Tarim Basin, China," Natural Gas Geoscience, vol. 14, no. 6, pp. 474-479, 2003.

[22] W. S. Hu, Y. S. Chen, A. C. Xiao, X. F. Liu, and S. G. Liu, “Tectonic evolution and petroleum system in the southwest depression of Tarim Basin," Petroleum \& Exploration Development, vol. 24, no. 1, pp. 14-17, 1997.

[23] Z. Du, C. Zeng, H. Qiu, and Y. Yang, "Key formations of the Permian hydrocarbon source rocks and oil-source correlation of Well KD1 in Yecheng Depression of southwestern Tarim Basin," Journal of Jilin University (Earth Science Edition), vol. 46, no. 3, pp. 651-660, 2016.

[24] Q. Wang, P. A. Peng, J. Zeng et al., "Oil source of condensates from Well Kedong 1 and crude oil from Kekeya in Yecheng depression," Geochimica, vol. 43, no. 5, pp. 469-476, 2014.

[25] J. B. Wang, Z. Q. Gao, Z. H. Kang, Y. X. Yang, D. Wei, and N. T. Qin, "The sedimentary environment and geochemical characteristics of the source rocks in the Pusige formation in Hetian Sag, southwestern Tarim Basin," Natural Gas Geoscience, vol. 28, no. 11, pp. 1723-1734, 2017. 
[26] X. M. Xiao, Q. H. Zeng, H. Tian, R. W. T. Wilkins, and Y. C. Tang, "Origin and accumulation model of the AK-1 natural gas pool from the Tarim Basin, China," Organic Geochemistry, vol. 36, no. 9, pp. 1285-1298, 2005.

[27] Y. C. Ding, "Strata division and correlation of CarboniferousPermian in western Tarim Basin," Journal of Xinjiang Petroleum Institute, vol. 7, no. 1, pp. 1-11, 1995.

[28] X. G. Li, "Characteristics of sequence stratigraphy and sedimentary system of Permian-Lower Triassic in Hetian area, Xinjiang province," Xinjiang Geology, vol. 29, no. 2, pp. 183-188, 2011.

[29] N. Liu, H. F. Zhang, S. C. Xiu, and Q. I. Xun, "Depositional environment in late Carboniferous-Early Permian in southern Hetian area of southwest Tarim Basin," Xinjiang Petroleum Geology, vol. 22, no. 4, pp. 316-319, 2001.

[30] M. M. Meng, Z. H. Kang, H. J. Qiu, S. Z. Li, and B. Bin, “Controlling factors of Permian hydrocarbon source rocks in the southwest depression of Tarim Basin," Bulletin of Mineralogy, Petrology Geochemistry, vol. 35, no. 2, pp. 344-352, 2016.

[31] H. C. Zhu, "Discovery of Late Permian spores and pollen from the Pusige Formation of Pishan, Xinjiang," Journal of Stratigraphy, vol. 21, no. 3, pp. 119-223, 1997.

[32] H. Dengfa, J. Chengzao, L. Desheng, Z. Chaojun, M. Qinren, and S. Xin, "Formation and evolution of polycyclic superimposed Tarim Basin," Oil \& Gas Geology, vol. 26, no. 1, pp. 64-77, 2005.

[33] Z. He, M. Gao, and M. Zheng, "Regional tectonic framework and evolution of superimposed basins in northwestern China," Earth Science Frontiers, vol. 22, no. 3, pp. 227-240, 2015.

[34] Y. Q. Zhang, The Coupling of Southwest Sag of Tarim Basin and West Kunlun Orogen, [M.S. thesis], China University of Geosciences, Beijing, 2006.

[35] J. T. Cui, J. C. Wang, X. W. Bian et al., “Zircon SHRIMP U-Pb dating of Early Paleozoic granite in the Menggubao-Pushou area on the northern side of Kangxiwar, West Kunlun," Geological Bulletin of China, vol. 26, no. 6, pp. 710-719, 2007.

[36] J. T. Cui, J. C. Wang, X. W. Bian, H. P. Zhu, and K. J. Yang, "Geological characteristics of Early Paleozoic amphibolite and tonalite in northern Kangxiwar, West Kunlun, China and their Zircon SHRIMP U-Pb dating," Geological Bulletin of China, vol. 25, no. 12, pp. 1441-1449, 2006.

[37] Y. H. Jiang, R. Y. Jia, Z. Liu, S.-Y. Liao, P. Zhao, and Q. Zhou, "Origin of Middle Triassic high-K calc-alkaline granitoids and their potassic microgranular enclaves from the western Kunlun orogen, northwest China: a record of the closure of Paleo-Tethys," Lithos, vol. 156-159, no. 1, pp. 13-30, 2013.

[38] B. Q. Li, J. X. Yao, W. H. Ji et al., "Characteristics and zircon SHRIMP U-Pb ages of the arc magmatic rocks in Mazar, southern Yecheng, West Kunlun Mountains," Geological Bulletin of China, vol. 25, no. 1-2, pp. 124-132, 2006.

[39] C. Wang, L. Liu, S. P. He et al., "Early Paleozoic magmatism in west Kunlun: constraints from geochemical and zircon U-PbHf isotopic studies of the Bulong granite," Chinese Journal of Geology, vol. 48, no. 4, pp. 997-1014, 2013.

[40] Z. H. Huishan, H. E. Shiping, and J. I. Wenhua, "Implications of late Cambrian granite in Tianshuihai massif for the evolution of proto-Tethy ocean: evidences from zircon geochronology and geochemistry," Acta Geologica Sinica, vol. 90, no. 10, pp. 2582-2602, 2016.

[41] X. J. Zhuang, L. X. Xiao, and J. Yang, "Sedimentary facies in southwestern region of Tarim Basin," Xinjiang Geology, vol. 20, no. z1, pp. 78-82, 2002.
[42] Henan Institute of Geological Survey, 1:250000 Scale YechengHetian Regional Geological Survey Report (in Chinese), Henan Institute of Geological Survey, 2004.

[43] K. E. Peters and M. R. Cassa, "Applied source rock geochemistry," in The Petroleum System-from Source to Trap, L. B. Magoon and W. G. Dow, Eds., vol. 60, pp. 93-120, American Association of Petroleum Geologists AAPG Memoir, Tulsa, Oklahoma, 1994.

[44] J. H. Dembicki, "Three common source rock evaluation errors made by geologists during prospect or play appraisals," $A A P G$ Bulletin, vol. 93, no. 3, pp. 341-356, 2009.

[45] R. A. Berner and R. Raiswell, "C/S method for distinguishing freshwater from marine sedimentary rocks," Geology, vol. 12, no. 6, pp. 365-368, 1984.

[46] W. Wei and T. J. Algeo, "Elemental proxies for paleosalinity analysis of ancient shales and mudrocks," Geochimica et Cosmochimica Acta, vol. 287, pp. 341-366, 2019.

[47] S. R. Taylor and S. M. McLennan, "The continental crust: its composition and evolution: an examination of the geochemical record preserved in sedimentary rocks," Blackwell, Oxford University, Oxford, 1985.

[48] W. V. Boynton, "Geochemistry of the rare earth elements: meteorite studies," Rare Earth Element Geochemistry, P. Henderson, Ed., pp. 63-114, 1984.

[49] S. M. McLennan, S. Hemming, D. K. Mcdaniel, and G. N. Hanson, "Geochemical approaches to sedimentation, provenance, and tectonics," in Processes Controlling the Composition of Clastic Sediments, M. J. Johnsson and A. Basu, Eds., pp. 21-40, Geological Society of America, Boulder, CO, USA, 1993.

[50] R. Cox, D. R. Lowe, and R. L. Cullers, “The influence of sediment recycling and basement composition on evolution of mudrock chemistry in the southwestern United States," Geochimica et Cosmochimica Acta, vol. 59, no. 14, pp. 29192940, 1995.

[51] C. M. Fedo, H. W. Nesbitt, and G. M. Young, "Unraveling the effects of potassium metasomatism in sedimentary rocks and paleosols, with implications for paleoweathering conditions and provenance," Geology, vol. 23, no. 10, pp. 921-924, 1995.

[52] H. W. Nesbitt and G. M. Young, "Early proterozoic climates and plate motions inferred from major element chemistry of lutites," Nature, vol. 299, no. 5885, pp. 715-717, 1982.

[53] H. W. Nesbitt and G. M. Young, "Prediction of some weathering trends of plutonic and volcanic rocks based on thermodynamic and kinetic considerations," Geochimica et Cosmochimica Acta, vol. 48, no. 7, pp. 1523-1534, 1984.

[54] G. Shields and P. Stille, "Diagenetic constraints on the use of cerium anomalies as palaeoseawater redox proxies: an isotopic and REE study of Cambrian phosphorites," Chemical Geology, vol. 175, no. 1-2, pp. 29-48, 2001.

[55] M. R. Bhatia, "Plate tectonics and geochemical composition of sandstones," Journal of Geology, vol. 91, no. 6, pp. 611-627, 1983.

[56] M. R. Bhatia, "Rare earth element geochemistry of Australian Paleozoic graywackes and mudrocks: provenance and tectonic control," Sedimentary Geology, vol. 45, no. 1-2, pp. 97-113, 1985.

[57] M. R. Bhatia and K. A. Crook, "Trace element characteristics of graywackes and tectonic setting discrimination of sedimentary basins," Contributions to Mineralogy Petrology, vol. 92, no. 2, pp. 181-193, 1986. 
[58] R. L. Cullers, "The controls on the major- and trace-element evolution of shales, siltstones and sandstones of Ordovician to tertiary age in the Wet Mountains region, Colorado, USA," Chemical Geology, vol. 123, no. 1, pp. 107-131, 1995.

[59] R. L. Cullers and V. N. Podkovyrov, "The source and origin of terrigenous sedimentary rocks in the Mesoproterozoic Ui group, southeastern Russia," Precambrian Research, vol. 117, no. 3-4, pp. 157-183, 2002.

[60] R. Feng and R. Kerrich, "Geochemistry of fine-grained clastic sediments in the Archean Abitibi greenstone belt, Canada: implications for provenance and tectonic setting," Geochimica et Cosmochimica Act, vol. 54, no. 4, pp. 1061-1081, 1990.

[61] K. I. Hayashi, H. Fujisawa, H. D. Holland, and H. Ohmoto, "Geochemistry of $\sim 1.9$ Ga sedimentary rocks from northeastern Labrador, Canada," Geochimica et Cosmochimica Acta, vol. 61, no. 19, pp. 4115-4137, 1997.

[62] D. J. Wronkiewicz and K. C. Condie, "Geochemistry of Archean shales from the Witwatersrand Supergroup, South Africa: source-area weathering and provenance," Geochimica et Cosmochimica Acta, vol. 51, no. 9, pp. 2401-2416, 1987.

[63] C. J. Allègre and J. F. Minster, "Quantitative models of trace element behavior in magmatic processes," Earth Planetary Science Letters, vol. 38, no. 1, pp. 1-25, 1978.

[64] S. Gao and K. H. Wedepohl, "The negative Eu anomaly in Archean sedimentary rocks: implications for decomposition, age and importance of their granitic sources," Earth Planetary \& Science Letters, vol. 133, no. 1-2, pp. 81-94, 1995.

[65] B. P. Roser and R. J. Korsch, "Determination of tectonic setting of sandstone-mudstone suites using $\mathrm{SiO}_{2}$ content and $\mathrm{K}_{2} \mathrm{O} / \mathrm{Na}_{2} \mathrm{O}$ ratio," Journal of Geology, vol. 94, no. 5, pp. 635$650,1986$.

[66] L. J. Feng, X. L. Chu, and Q. R. Zhang, "CIA (chemical index of alteration) and its application in the Neoproterozoic clastic rocks," Earth Science Frontiers, vol. 10, no. 4, pp. 539-544, 2003.

[67] J. Cao, M. Wu, Y. Chen et al., "Trace and rare earth element geochemistry of Jurassic mudstones in the northern Qaidam Basin, northwest China," Chemie der Erde-Geochemistry, vol. 72, no. 3, pp. 245-252, 2012.

[68] W. Getaneh, "Geochemistry provenance and depositional tectonic setting of the Adigrat sandstone northern Ethiopia," Journal of African Earth Sciences, vol. 35, no. 2, pp. 185-198, 2002.

[69] Z. D. Jin and E. L. Zhang, "Paleoclimate implications of Rb/Sr ratios from lake sediments," Science and Technology Engineering, vol. 2, no. 3, pp. 20-22, 2002.

[70] K. Tanaka, F. Akagawa, K. Yamamoto, Y. Tani, I. Kawabe, and T. Kawai, "Rare earth element geochemistry of Lake Baikal sediment: its implication for geochemical response to climate change during the Last Glacial/Interglacial transition," Quaternary Science Reviews, vol. 26, no. 9-10, pp. 1362-1368, 2007.

[71] J. B. Wang, Z. L. He, and D. Y. Zhu, "Geochemical characteristics, depositional environment, and provenance attitude of the Middle Jurassic Yangye Formation lacustrine mudstones in Kashi Sag, south-western Tarim Basin," Geological Journal, vol. 55, no. 4, pp. 2976-2994, 2020.

[72] Z. Y. Zhao, J. H. Zhao, and H. J. Wang, "Distribution characteristics and applications of trace elements in Junggar Basin," Natural Gas Exploration Development, vol. 30, no. 2, pp. 3032, 2007.
[73] T. J. Algeo and J. S. Liu, “A re-assessment of elemental proxies for paleoredox analysis," Chemical Geology, vol. 540, 2020.

[74] H. Kimura and Y. Watanabe, "Oceanic anoxia at the Precambrian-Cambrian boundary," Geology, vol. 29, no. 11, pp. 995-998, 2001.

[75] Z. Wang, J. Wang, X. Fu et al., "Organic material accumulation of Carnian mudstones in the North Qiangtang Depression, eastern Tethys: controlled by the paleoclimate, paleoenvironment, and provenance," Marine \& Petroleum Geology, vol. 88, pp. 440-457, 2017.

[76] P. B. Wignall and R. J. Twitchett, "Oceanic anoxia and the end Permian mass extinction," Science, vol. 272, no. 5265, pp. 1155-1158, 1996.

[77] T. Hu, X. Q. Pang, S. Jiang et al., "Impact of paleosalinity, dilution, redox, and paleoproductivity on organic matter enrichment in a saline lacustrine rift basin: a case study of Paleogene organic-rich shale in Dongpu depression, Bohai Bay Basin, Eastern China," Energy \& Fuels, vol. 32, no. 4, pp. 5045-5061, 2018.

[78] Y. Q. Guo, F. Yu, Y. Li et al., "Geochemical characteristics of sedimentary environment on He 8 Member of Shihezi Formation in eastern Ordos Basin," Chinese Journal of Geology, vol. 51, no. 3, pp. 872-890, 2016.

[79] S. Q. Mei, “Application of rock chemistry in the study of Presinian sedimentary environment and the source of uranium mineralization in Hunan Province," Hunan Geology, vol. 7, no. 3, pp. 25-34, 1988.

[80] N. Tribovillard, T. J. Algeo, F. Baudin, and A. Riboulleau, "Analysis of marine environmental conditions based on molybdenum-uranium covariation: applications to Mesozoic paleoceanography," Chemical Geology, vol. 324-325, pp. 46$58,2012$.

[81] L. Zhai, C. Wu, Y. Ye, S. Zhang, and Z. An, "Marine redox variations during the Ediacaran-Cambrian transition on the Yangtze Platform, South China," Geological Journal, vol. 53, pp. 58-79, 2016.

[82] T. D. Adams, J. R. Haynes, and C. T. Walker, "Boron in Holocene illites of the Dovey estuary, Wales, and its relationship to palaeosalinity in cyclothems," Sedimentology, vol. 4, no. 3, pp. 189-195, 1965.

[83] E. L. Couch, "Calculation of paleosalinities from boron and clay mineral data," AAPG Bulletin, vol. 55, no. 10, pp. 1829$1837,1971$.

[84] C. T. Walker, "Evaluation of boron as a paleosalinity indicator and its application to offshore prospects," AAPG Bulletin, vol. 52, no. 5, pp. 751-766, 1968.

[85] C. T. Walker and N. B. Price, "Departure curves for computing paleosalinity from boron in illites and shales," AAPG Bulletin, vol. 47, pp. 833-841, 1963.

[86] R. C. Zheng and M. Q. Liu, "Study on palaeosalinity of Chang6 oil reservoir set in Ordos Basin," Oil \& Gas Geology, vol. 20, no. 1, pp. 20-25, 1999.

[87] K. E. Peters, C. C. Walters, and J. M. Moldowan, The Biomarker Guide, Cambridge University Press, Cambridge, UK, 2nd edition, 2005.

[88] Y. S. Pan, Z. L. Huang, T. L. Li, X. Guo, X. Xu, and X. Chen, "Environmental response to volcanic activity and its effect on organic matter enrichment in the Permian Lucaogou Formation of the Malang Sag, Santanghu Basin, Northwest China," Palaeogeography Palaeoclimatology Palaeoecology, vol. 560, article 110024, 2020. 
[89] Z. H. Chen, M. Zha, and Q. Jin, "Mineral elemental response to the evolution of terrestrial brine faulted-basin: a case study in the Paleogene of Well Haoke-1, Dongying Sag," Acta Sedimentologica Sinica, vol. 26, no. 6, pp. 925-932, 2008.

[90] T. Tenger, W. H. Liu, and Y. C. Xu, "Comprehensive geochemical identification of highly evolved marine hydrocarbon source rocks: organic matter, paleoenvironment and development of effective hydrocarbon source rocks," Chinese Journal of Geochemistry, vol. 25, pp. 333-340, 2006. 